Board of Governors of the Federal Reserve System

International Finance Discussion Papers

Number 1315

April 2021

\title{
Supply of Sovereign Safe Assets and Global Interest Rates
}

\author{
Thiago Ferreira and Samer Shousha
}

\begin{abstract}
Please cite this paper as:
Ferreira, Thiago, and Samer Shousha (2021). "Supply of Sovereign Safe Assets and Global Interest Rates," International Finance Discussion Papers 1315. Washington: Board of Governors of the Federal Reserve System, https://doi.org/10.17016/IFDP.2021.1315.
\end{abstract}

NOTE: International Finance Discussion Papers (IFDPs) are preliminary materials circulated to stimulate discussion and critical comment. The analysis and conclusions set forth are those of the authors and do not indicate concurrence by other members of the research staff or the Board of Governors. References in publications to the International Finance Discussion Papers Series (other than acknowledgement) should be cleared with the author(s) to protect the tentative character of these papers. Recent IFDPs are available on the Web at www.federalreserve.gov/pubs/ifdp/. This paper can be downloaded without charge from the Social Science Research Network electronic library at www.ssrn.com. 


\title{
Supply of Sovereign Safe Assets and Global Interest Rates*
}

\author{
Thiago Ferreira ${ }^{\dagger}$ and Samer Shousha ${ }^{\ddagger}$ \\ Federal Reserve Board
}

\begin{abstract}
We estimate that the supply of sovereign safe assets is a major driver of neutral interest rates - real rates consistent with both economic activity and inflation at their trends. We find this result using an empirical cross-country model with many economic drivers for the neutral rates of 11 advanced economies during the 1960-2019 period. The increasing availability of safe assets after 2008 has pushed up neutral rates, preventing them from continuing their previous decline because of other drivers. We also evaluate the "global savings glut" hypothesis. We estimate that since 1994 the global accumulation of international exchange reserves in safe assets has lowered the availability of these assets to the private sector and, thus pushed down neutral rates. Finally, we find that economies' neutral rates are subject to important global spillovers from developments in other economies.
\end{abstract}

Key Words: neutral interest rates, safe assets, international reserves, global savings glut. JEL Classification: E21, E43, E52.

*This paper was previously circulated under the title "Scarcity of Safe Assets and Global Neutral Interest Rates." This version: March 2021. First version: June 2019. The views expressed in this paper are solely our responsibility and should not be interpreted as reflecting the views of the Board of Governors of the Federal Reserve System or of any other person associated with the Federal Reserve System. We would like to thank for very useful comments and suggestions from Shaghil Ahmed, Richard Clarida, Christopher Erceg, Etienne Gagnon, Marc Giannoni, Simon Gilchrist, Nils Gornemann, Joseph Gruber, Andrea Pescatori, Andrea Raffo, Ricardo Reyes-Heroles, Marcelo Rezende, John Rogers, Frank Warnock, and seminar participants at the Federal Reserve Board, the International Monetary Fund, Dallas Fed, and Atlanta Fed. We are very grateful about the remarks from anonymous referees. We would also like to thank the outstanding research assistance of Caitlin Dutta, Kaede Johnson, Isabel Juniewicz, Ben Smith, Lizzy Stanton, and Nicolas Savignon.

${ }^{\dagger}$ Division of International Finance, Federal Reserve Board, 20th and C St. NW, Washington, DC 20551. Email: thiago.r.teixeiraferreira@frb.gov.

${ }^{\ddagger}$ Division of International Finance, Federal Reserve Board, 20th and C St. NW, Washington, DC 20551. Email: samer.f.shousha@frb.gov. 


\section{Introduction}

Researchers have analyzed many economic drivers of trends in global interest rates. A common feature in these analyses is that they build on the savings-and-investment framework, which has similar predictions for interest rates of different types of assets. However, these predictions are at odds with the empirical evidence: real rates on safe assets have declined since the early 1990s (e.g., Figure 1), while the return on private capital has remained relatively constant (Gomme et al., 2011; Jorda et al., 2019; Reis, 2020). Our paper departs from the savings-and-investment framework and studies global neutral interest rates — real rates consistent with both economic activity and inflation at their trends - focusing on the demand and supply of safe assets.

As opposed to other studies, we directly quantify the role of the supply of sovereign safe assets in determining neutral rates using an empirical cross-country model with many possible economic drivers. ${ }^{1}$ To do so, we first measure the global net supply of safe assets available to the private sector. We calculate the supply of sovereign safe assets net of foreign governments' exchange reserve holdings and assets never traded in secondary markets. In our benchmark series, we focus on U.S. Treasury securities because of the central role of the U.S. dollar in the global trade, financial, and monetary systems (Gourinchas et al., 2019). We then propose a theoretical framework to guide our empirical approach, showing that the existence of a preference for safe assets implies that their supply can be an important determinant of neutral rates. Our theoretical framework builds on Krishnamurthy and Vissing-Jorgensen (2012) and the literature that views this preference for safe assets as a demand for the safety and liquidity found in, for instance, U.S. Treasuries. ${ }^{2,3}$

We then estimate an empirical cross-country model with neutral interest rates for 11 advanced economies. The model has two previously unexplored features. First, it simultaneously includes many potential determinants of neutral rates and incorporates the statistical

\footnotetext{
${ }^{1}$ Glick (2020) provides evidence that foreign demand for U.S. safe assets started to increase before 2008, leading him to conjecture that this demand pushed down neutral rates. Del Negro et al. (2019) find convenience yields to be a significant driver of global neutral rates, which they interpret as pointing to an "imbalance between the global demand for safety and liquidity and its supply."

${ }^{2}$ Our model is also consistent with the view that safe rates are determined in a market in which institutional investors, such as pension funds, show a particular preference for safe assets because of, among other issues, regulatory measures. (Caballero and Farhi, 2018).

${ }^{3}$ This preference for safe assets can arise from regulatory measures or the relatively higher risk aversion of some agents, such as pension funds and insurance firms, holding specific shares of safe assets in their portfolios as shown by Greenwood and Vissing-Jorgensen (2018)
} 


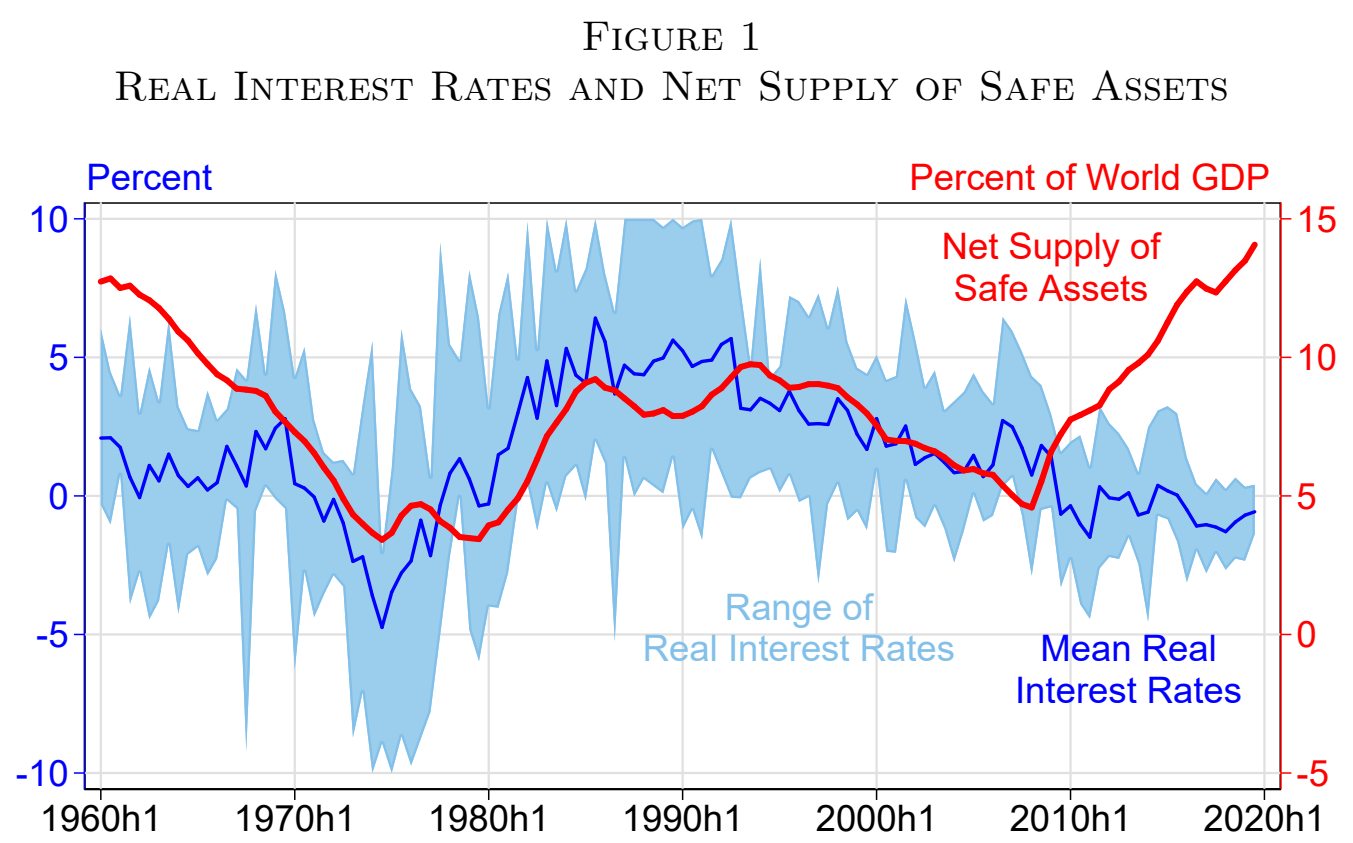

Note: Shaded blue area displays the range of real interest rates, measured by policy rates minus realized inflation. Solid blue line is the mean real interest rate. Our sample covers the following economies: Australia, Canada, Denmark, the euro area, Japan, Norway, New Zealand, Sweden, Switzerland, the United Kingdom, and the United States. For a better exposition, we exclude values of real rates greater than $10 \%$ and less than negative 10\%. The red line is our measure of net supply of U.S. Treasuries (Section 2.2).

uncertainty around the relevance of these determinants. ${ }^{4}$ In addition to estimating global effects from the net supply of safe assets, our model uses data on productivity, demographics, and the convenience yield, with the latter as a proxy for factors that may increase the demand for safe assets, such as regulatory reforms (e.g., Caballero et al., 2017) and macroeconomic risk (e.g., Farhi and Gourio, 2018). Second, our cross-country model captures the theoretical prediction that, in financially open economies, interest rates are determined by global market forces, and, thus, developments abroad can exert a decisive force on domestic neutral rates (Obstfeld, 2020, Clarida, 2019). Specifically, we allow the neutral rate of a particular economy to be subject to global spillovers from determinants of other economies.

The main finding of our paper is that the net supply of safe assets is a major driver of neutral rates. We estimate that changes in the net supply of safe assets account for an average of $37 \%$ of the variance of neutral rates across countries. Moreover, net safe assets contributed to the path of neutral rates in important periods of our sample: a decline in the 1960s-70s, a rebound in the early 1980s, and the steady decline during the 2000s. Since

\footnotetext{
${ }^{4}$ Other studies either focus on a restricted set of neutral rate determinants or rely on correlations between these determinants and ex-post calculated neutral interest rates. For instance, see Del Negro et al. (2019), Lunsford and West (2019), Hamilton et al. (2016).
} 
2008, the increasing availability of net safe assets has prevented neutral rates from declining further because of other factors, such as a higher convenience yield and transitioning demographics. We estimate that the larger net safe asset supply has positively contributed 1.5 percentage points to global neutral rates since 2008. Figure 1 illustrates these results, with net supply of safe assets co-moving well with real rates until 2008 and rising thereafter. Moreover, our results are consistent with the idea that larger debts from advanced countries have boosted the supply of safe assets after 2008, while higher demand for these assets due to, for instance, regulatory reforms and older population, has pushed down neutral rates.

We also evaluate the "global savings glut" hypothesis (Bernanke, 2005). According to this theory, a global excess of desired savings over desired investment emanating largely from government policy decisions, such as the concerted efforts of emerging market economies to reduce borrowing and build international reserves after the financial crises of the 1990s, was a major reason for low global interest rates (Bernanke, 2015). In our evaluation, we calculate neutral rates using a counterfactual path of the net supply of safe assets in which foreign official holdings of U.S. Treasuries stays constant (as a percentage of world GDP) at the 1993 level from 1994 to 2019. We estimate that the accumulation of international reserves reduced U.S. neutral rates by 65 basis points in 2015 (relative to the counterfactual net safe assets) and by 50 basis points in 2019 .

Finally, we find that economies' neutral rates are subject to important global spillovers from developments in other economies. First, these spillovers play a significant role in explaining the trajectories of neutral rates. For instance, we estimate that rest-of-the-world's productivity slowdown and demographic transition reduced U.S. neutral rates by 85 basis points during the 2000-2019 period. Second, global spillovers help explain the international co-movement of neutral rates. Our model has three types of drivers contributing to a statistical global common factor in neutral rates (Kiley, 2019; Del Negro et al., 2019): global determinants (net safe assets and convenience yield), synchronized behavior in economy-specific determinants (productivity and demographics), and global spillovers of these economy-specific determinants. We calculate the amount of co-movement implied by each one of these three types of drivers and find a high co-movement implied by global spillovers.

This paper speaks to the large literature evaluating the determinants of neutral interest rates around the world. ${ }^{5}$ However, this literature is largely motivated by the savings-and-

\footnotetext{
${ }^{5}$ For a literature review, see Brand et al. (2018).
} 
investments framework. Several authors highlight the role of demographic transition as a driver of neutral rates (e.g., Krueger and Ludwig, 2007; Carvalho et al., 2016; Gagnon et al., 2016; Aksoy et al., 2019). Other researchers argue for a prominent role of trend gross domestic product (GDP) in explaining interest rates (e.g., Laubach and Williams, 2003; Holston et al., 2017; Jorda and Taylor, 2019; Lunsford and West, 2019), despite some evidence disputing this importance (Hamilton et al., 2016). More recently, some papers have argued for the importance of safe asset scarcity (Glick, 2020; Del Negro et al., 2019). As opposed to these previous studies, our paper (i) adopts an approach focused on the demand-vs.-supply of safe assets; (ii) explicitly calculates a measure of sovereign safe asset supply; (iii) evaluates the role of the global savings glut; (iv) statistically allows for many potential explanations for neutral rates; and (v) finds that the net safe asset supply is an important driver of neutral rates, (vi) with global spillovers also playing a relevant role.

Our paper also contributes to a growing body of literature that researches the global scarcity of safe assets and its effects in the real economy. In a series of papers, Caballero et al. (2016), Caballero et al. (2017), and Caballero and Farhi (2018) argue that a growing demand for safe assets in countries with less-developed financial markets pushes down the short-term equilibrium interest rate in safe-asset-producing economies. Moreover, Caballero et al. (2021) argue that safe asset scarcity has global implications, as net safe asset producers export these assets to net safe asset absorbers until interest rates are equalized across countries, acting as a global factor on interest rates across countries. Our finding of net sovereign safe assets as a global driver of neutral rates provides empirical support to these theoretical results.

Outline. The rest of the paper is organized as follows. Section 2 presents a theoretical framework under which the net supply of safe assets is an important determinant of neutral rates and details our measure of global net supply of safe assets. Section 3 describes our cross-country state-space model. Section 4 discusses the main results of the paper and the many robustness checks. Section 5 concludes and explores potential extensions.

\section{Scarcity of Safe Assets: Theory and Measurement}

In this section, we present a theoretical framework under which the availability of safe assets is an important determinant of neutral interest rates (Section 2.1), and we propose a measure of the global supply of sovereign safe assets (Section 2.2). Finally, we discuss how 
we empirically capture other potential determinants of neutral rates (Section 2.3).

\subsection{Safe Asset Scarcity: A Determinant of Neutral Interest Rates}

Following Krishnamurthy and Vissing-Jorgensen (2012), our framework has one deviation from the canonical representative household of most business cycle models: the household derives utility from holding safe assets.

Specifically, the representative agent maximizes

$$
\begin{array}{r}
\mathbb{E}_{0} \sum_{t=0}^{\infty} \delta^{t} u\left(C_{t}\right), \\
u\left(C_{t}\right)=\log \left[c_{t}+\nu\left(\theta_{t} ; \xi_{t}\right)\right],
\end{array}
$$

where $\delta$ is the inter-temporal discount factor, $c_{t}$ is period $t$ 's consumption, and $\nu(\cdot)$ is the benefit from from holding safe assets, $\theta_{t}$, which in this paper we narrow down to Treasury securities of advanced economies (see Section 2.2). We assume an increasing benefit of holding additional safe assets, $\nu^{\prime}>0$, but at a decreasing marginal rate, $\nu^{\prime \prime}<0$. For simplicity, $\theta_{t}$ represents holdings of safe assets normalized by the income of the representative household, the Gross Domestic Product (GDP). ${ }^{6}$ The utility derived from safe assets is a modeling device for, among other issues, (i) benefits related to their liquidity, which reduces transaction costs relative to other securities such as corporate bonds, and (ii) institutional arrangements related to their safety, such as specific portfolio shares of retirement savings in Treasury securities as used by many pension funds. We also allow for other motives, $\xi_{t}$, to shift the household preferences for safe assets.

To show how the preference for safe assets may affect long-run neutral interest rates in this framework, we derive the steady-state interest rate of a one-period bond. Under general conditions of balanced growth path (see Appendix A for derivation details), the

\footnotetext{
${ }^{6}$ Regarding Equation (1), we assume that the utility from holding safe assets is homogeneous of degree one in the real income of the representative agent, $\mathrm{GDP}_{t}$, and real safe asset holdings, $\Theta_{t}$ :

$$
\nu\left(\Theta_{t}, \mathrm{GDP}_{t} ; \xi_{t}\right)=\mathrm{GDP}_{t} \cdot \nu\left(\theta_{t} ; \xi_{t}\right), \quad \text { where } \theta_{t}=\frac{\Theta_{t}}{\mathrm{GDP}_{t}}
$$

In Equation (1), for expositional purposes, we abuse notation and omit the dependence of $\nu(\cdot)$ on $\mathrm{GDP}_{t}$. See Appendix A for the full description of the household problem.
} 
steady-state real interest rate, $R$, is the following:

$$
R=\left[1-\nu^{\prime}(\theta ; \xi)\right] \frac{g}{\delta}
$$

where $g$ is the steady-state growth rate.

Equation (2) shows that the mere existence of a preference for holding safe assets $\left(\nu^{\prime} \neq 0\right)$ allows for the supply of these assets to become an important determinant of neutral interest rates. When $\theta$ is low and the supply of safe assets is scarce, the marginal benefit $\left(\nu^{\prime}\right)$ of these assets increases, thus increasing their price and decreasing their interest rate. Conversely, if $\theta$ is high and the supply of safe assets is abundant, their marginal benefit decreases, thus decreasing their price and increasing their interest rate. Another important takeaway from Equation (2) is that the amount of safe assets determining long-run real rates is the amount available to the private sector, which is the marginal buyer in this framework. Thus, government policies that decrease the availability of safe assets to the private sector, such as foreign exchange reserve accumulation, exert downward pressure on interest rates because safe assets become scarcer to those pricing it.

Persistent changes in the preference for safe assets, $\xi$, may also influence neutral longrun interest rates. For instance, regulatory reforms may increase the desire of financial institutions to hold government safe assets, for any given interest rate observed in debt markets (e.g., Caballero et al., 2017). Additionally, an increase in macroeconomic risk, a decrease in agents' tolerance to such risk, or intensified precautionary savings motives (e.g., Farhi and Gourio, 2018, and De Paoli and Zabczyk, 2013) may also increase the demand for safe assets. Finally, traditionally studied determinants of neutral interest rates might also be interpreted as preference shifters for safe assets. For example, an aging population might cause an increase not only in total savings, but also in the share of safe assets relative to risky assets, as aging savers re-allocate their portfolio towards safe assets to guarantee a steady stream of income after retirement.

\subsection{Global Supply of Safe Assets to the Private Sector}

We adopt a narrow definition of a safe asset: a simple debt instrument that is expected to preserve its value during any event and that has ample market liquidity. Moreover, we focus on sovereign safe assets, as sovereigns' ability to levy taxes inherently makes 
their debt safer relative to that of the private sector. ${ }^{7}$ However, a country can produce safe assets if, and only if, it has good protection of property rights; no default risk; a good track record of exchange rate and price stability; and deep, liquid, and open financial markets. This definition leads to a gross supply of safe assets concentrated in a few advanced economies. Additionally, there is extensive evidence of the central role of the U.S. dollar in the global trade, financial, and monetary systems, with an increasing share since the end of Bretton Woods in trade invoicing, international debt and loans issuance, foreign central banks' international reserves, and foreign exchange turnover. ${ }^{8}$ Consequently, in our baseline specification, we will use only U.S. government bonds in our measure of safe assets. ${ }^{9}$

We are interested in the supply of safe assets available to price-sensitive buyers, as they should be the marginal investors and, thus, determine market prices. Therefore, gross debt levels are misleading for our purposes. For instance, a considerable share of U.S. government debt is in the hands of public entities. These intragovernmental holdings are debt obligations that a government owes to its own agencies, including, for example, Medicare trust funds, the Social Security Trust Fund, and Federal Financing Bank securities for the United States. We then consolidate all of these intragovernmental holdings and other non-marketable government debt into one measure of non-marketable debt, which we later exclude from total U.S. gross government debt.

We also account for the evidence that the demand of foreign governments for U.S. government bonds is price inelastic. ${ }^{10}$ To do so, we follow the discussion of Section 2.1 and focus on the supply of safe assets available to the private sector, which are the marginal buyers, and, consequently, more price-sensitive. Thus, we measure the amount of safe assets in the hands of foreign governments to then exclude this amount from the gross supply of

\footnotetext{
${ }^{7}$ See Caballero et al. (2017) and Pascal and Perotti (2017) for similar definitions for safe assets.

${ }^{8}$ See Gourinchas et al. (2019) and Gourinchas (2019) for evidence on the hegemony of the dollar. He et al. (2019) propose a model that rationalizes the hegemony of the dollar. Ilzetzki et al. (2019) document factors that likely have limited the euro's role as an anchor currency and global safe asset.

${ }^{9}$ Gorton et al. (2012) propose a broader measure which includes some private assets. However, Gorton and Ordonez (2020) acknowledge that private assets are not perfect substitutes to public safe assets, as the information about their quality is more heterogeneous. Consistent with this claim, Boyarchenko et al. (2019) show that spreads on mortgage backed securities (MBS) backed by U.S. agencies reached high levels in turbulent periods (e.g., 1998 and the 2008), and have robust correlations with credit spreads, suggesting that risk capacity of financial intermediaries are important determinants of MBS spreads.

${ }^{10}$ Gourinchas and Jeanne (2013) show that capital flows from rich to poor countries are poorly explained by productivity growth, with the accumulation of international reserves playing an important role in the puzzle. Moreover, according to the World Bank's survey on central banks' reserve management (Alekasir et al., 2019), investments are concentrated in high-quality fixed-income assets, with safety and liquidity as high priorities.
} 


\section{FIGURE 2}

\section{Building Measure of Net Supply of Safe Assets}

(A) Net Safe Assets: United States

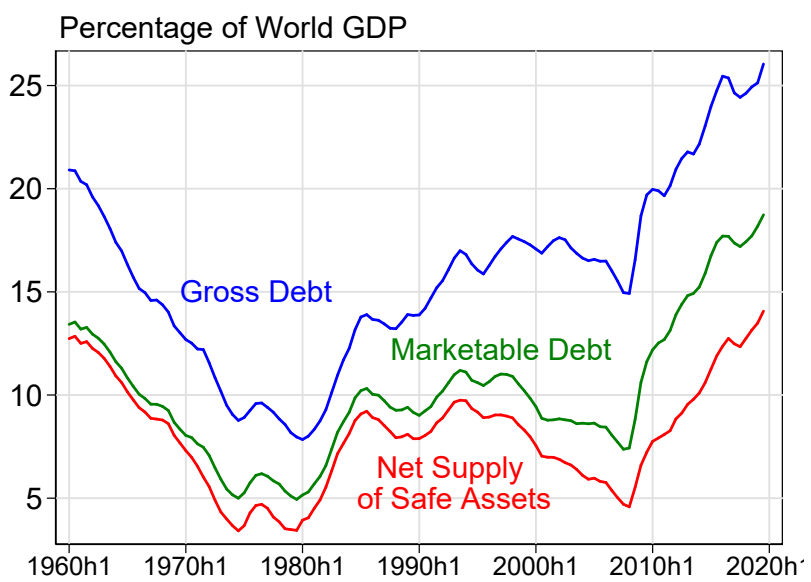

(B) Net Safe Assets: Advanced Economies

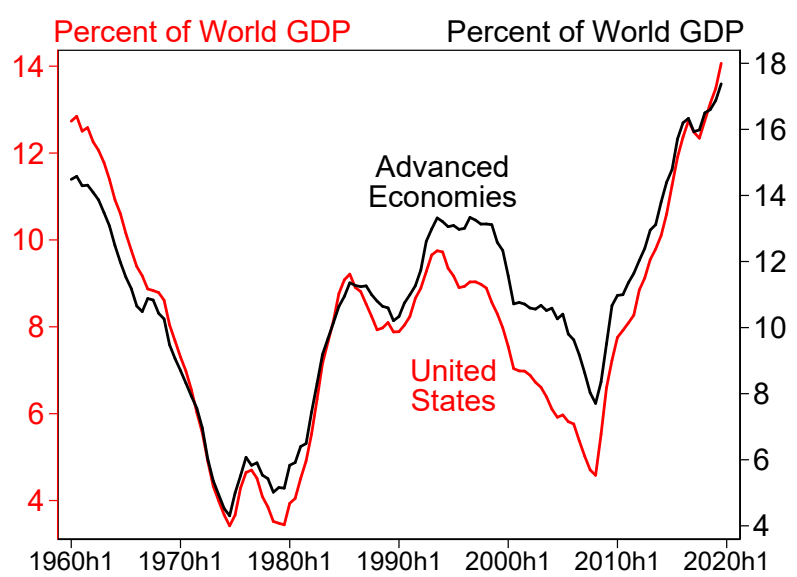

Note: All figures are in percent of world GDP. Gross debt is the gross government debt of the United States. Marketable debt includes government bonds that are transferable and can be bought and sold on the secondary market. Net safe assets are marketable debt in the hands of the private sector-i.e., it excludes foreign government holdings from total marketable debt. The net supply of safe assets measure for advanced economies includes bonds from governments of the United States, Germany, France, and the United Kingdom. Sources are listed in Appendix B.

safe assets. We calculate the amount of safe assets in the hands of foreign governments using data from the IMF Currency Composition of Official Foreign Exchange Reserves (COFER) database and the Treasury International Capital reporting system (TIC), adjusted following the methodology in Bertaut and Judson (2014). We add all foreign official holdings of shortand long-term U.S. Treasury securities.

We then proceed to the calculation of our measure of supply of safe assets available to the private sector. First, we exclude non-marketable debt from the gross supply of government bonds (blue line in Figure 2a) to get a measure of marketable debt (green line in Figure 2a). Then, we exclude foreign official holdings from the measure of marketable debt, getting the net supply of safe assets (red line in Figure 2a). All of these measures are normalized by the world GDP measured in U.S. dollars to capture the idea that investors around the world hold these assets. Our baseline measure of net safe asset supply to the private sector was at historically low levels during the 1970s, increasing in the 1980s. It then gradually declined from the mid-1990s to 2007, because of improvements in the U.S. fiscal balance and the surge in international reserve holdings by emerging market economies. Starting in 
2008, the net supply of safe assets sharply increased because of U.S. fiscal deficits, with the 2019 level of safe assets being comparable to the one of 1960 .

Given the historical importance of German, French, and British government bonds as means of storage of value in the international context, we also construct an analogous measure of net supply of safe assets including these bonds on top of the U.S. Treasuries. ${ }^{11}$ Figure $2 \mathrm{~b}$ shows that our baseline U.S.-based measure of net safe assets is very similar to our broader one, and both measures yield similar results in our model (Section 4.7). Finally, if we exclude Treasury holdings of the Federal Reserve from the net supply of safe assets, we also get similar results (Section 4.7, with detailed discussion in Appendix D).

\subsection{Other Drivers of Neutral Interest Rates}

This section describes the additional variables included in our state-space model, as well as the economic channels through which these variables might affect neutral rates. Data details are in Appendix B.

We start by including productivity growth, with at least two economic reasons to do so. First, when productivity growth slows down, it reduces investment opportunities, decreasing investment demand. Second, lower productivity growth also lowers expected income for households, increasing their precautionary savings. Consequently, within a savings-andinvestment framework, lower productivity growth should drive down neutral interest rates because of both lower investment demand and higher savings. ${ }^{12}$ We then use a measure of productivity growth that is the trend of an average of four different yearly measures of productivity: total factor productivity (TFP), GDP per person employed, and two measures of GDP per hour worked. Our measure of trend-productivity growth was historically high in the 1960s, experienced a substantial decline in the early 1970s, had some fluctuations in the 1980s and 1990s, and decreased again in the early 2000s (Figure 3a).

We also include demographic variables, as several authors also highlight their role as a determinant of neutral interest rates with many economic channels at work (e.g., Krueger and Ludwig (2007); Carvalho et al. (2016); Gagnon et al. (2016)). In addition to the possible effects from the preference-for-safe-assets channel discussed in Section 2.1 ( $\xi$ of Equation

\footnotetext{
${ }^{11}$ Appendix B provides the details of the calculation of this broader measure of net safe assets including German, French, and British government bonds.

${ }^{12}$ While the theoretical relationship between productivity growth and neutral interest rates is compelling, the empirical evidence on this relationship is less straightforward, especially in very long samples, as discussed by Hamilton et al. (2016) and Lunsford and West (2019).
} 
(2)), an aging population might lower neutral rates through (i) an increase in the retirement period; (ii) a reduction in labor supply (and a consequent increase in the capital-labor ratio) which reduces the marginal product of capital; and (iii) a lower rate of innovation (Aksoy et al. (2019)). We summarize demographic developments using the working-age population share, measured as the ratio of those aged between 20 and 60 over total population. ${ }^{13}$ The working-age population share has evolved with an inverted U-shape, being historically low in the 1960s, reaching a peak around the mid-1990s, and decreasing since then (Figure 3b). In Section 4.7, we show that our results are robust to other demographic variables.

Lastly, we include a measure of convenience yield, the value investors assign to the liquidity and safety attributes offered by U.S. Treasury securities. ${ }^{14}$ As discussed in Del Negro et al. (2019), this variable may point to an imbalance between demand and supply of safe assets, thus capturing additional demand factors for safe assets beyond demographics (represented by $\xi$ of Equation (2)). For instance, the convenience yield may reflect (i) regulatory changes that increase holdings of Treasuries by financial institutions and (ii) a stronger desire to hedge against macroeconomic risk due to either increased risks or lower risk tolerance. To construct the measure of convenience yield (black line of Figure 3c), we use an approach similar to Gilchrist and Zakrajšek (2012): we calculate bond-by-bond spreads between AA-or-higher corporate bond yields and U.S. Treasury yields with the same maturity and use the median of these spreads at every time period. ${ }^{15}$ We then focus on the trend of the convenience yield (red line of Figure 3c). After some fluctuations in the beginning of the sample, the convenience yield trend has steadily increased since the mid-1990s.

We focus on the trend of productivity growth and convenience yield to bypass cyclical fluctuations and focus on long-run developments. This approach is consistent with the model of Section 2.1, which predicts that it is the long-run values of these variables that determine neutral rates. In our baseline specification, we use the Hodrick-Prescott (HP) filter with very high smoothing parameters to focus on the low-frequency movements of

\footnotetext{
${ }^{13}$ Lunsford and West (2019) find that the long-run correlation of the safe real interest rates with labor force hours growth is positive, supporting the choice of the working-age population share.

${ }^{14}$ Krishnamurthy and Vissing-Jorgensen (2012) show a strong negative relation between the spread of AA-rated corporate bonds over U.S. Treasury yields and the outstanding amount of U.S. government debt held by the public normalized by U.S. GDP. They also provide evidence that this negative relation reflects a demand curve for the higher safety and liquidity of Treasuries.

${ }^{15}$ The measure of convenience yield used by Del Negro et al. (2019) is the aggregate Moody's Baa corporate bond yields minus U.S. Treasury yield.
} 
FIGURE 3

Determinants of Real Neutral Interest Rates

(A) Trend-Productivity Growth

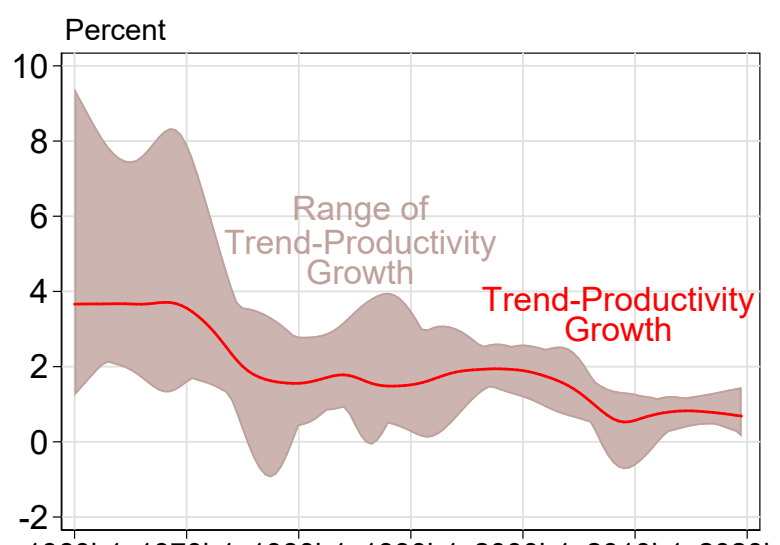

(c) Convenience Yield

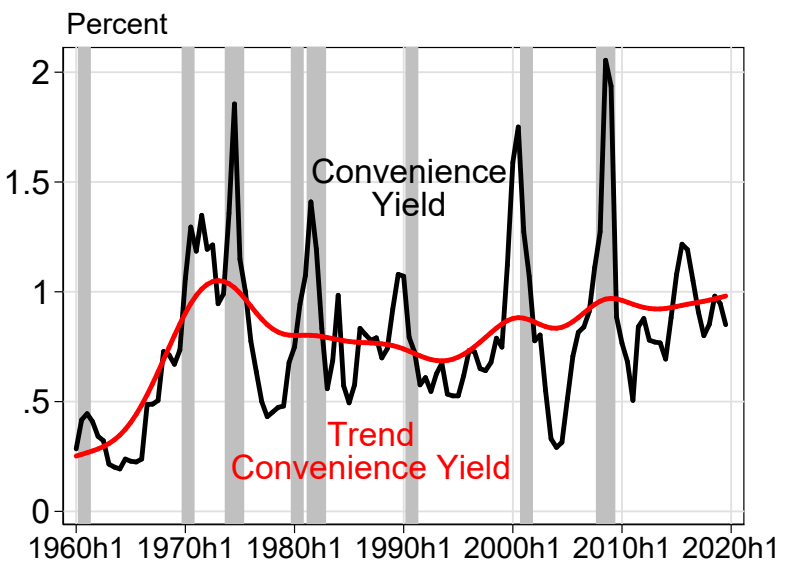

(B) Working-Age Population Share

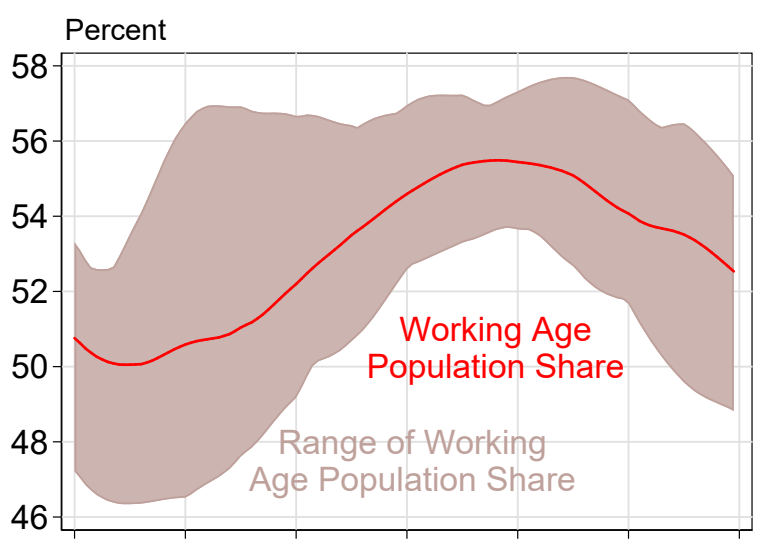

1960h1 1970h1 1980h1 1990h1 2000h1 2010h1 2020h1

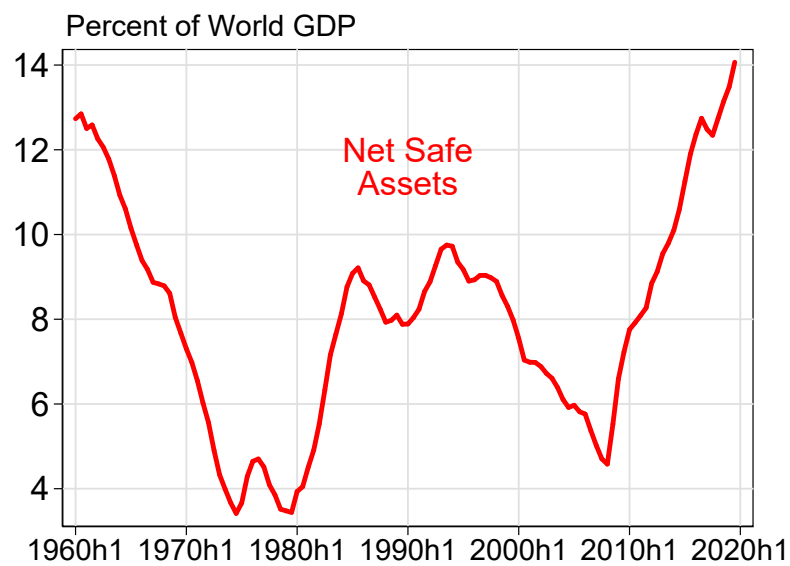

Note: Shaded red areas denote the maximum and minimum of a variable across countries, while the solid line is the cross-country mean. Trend-productivity growth is the trend of an average of four different measures of trend-productivity growth. Working-age population share is the ratio of those aged 20 to 60 over total population. Convenience yield is the spread between AA+ corporate bond yields and U.S. Treasury yields, with the trend bypassing cyclical fluctuations. Horizontal shadings in Figure 3c indicate periods classified as recessions by the NBER. Data details are in Appendix B. 
these variables. This choice is based on the results from Hodrick (2020), which shows that the HP filter performs better than other detrending techniques in variables with trend components that vary slowly over time (such as in Figures 3a and 3c). In Section 4.7, we show that our results are robust to other detrending methods, such as Hamilton (2018). ${ }^{16}$

\section{Cross-Country State-Space Model}

In this section, we build on Uribe (2021) and construct a panel cross-country state-space model to estimate neutral interest rates for 11 advanced economies using half-yearly data. ${ }^{17}$

\subsection{Model Specification}

For economy $j$ at time period $t$, we model the cyclical and trend components of the unemployment, $u_{j, t}$, inflation, $\pi_{j, t}$, and policy, $i_{j, t}$, rate as follows:

$$
\begin{aligned}
{\left[\begin{array}{c}
u_{j, t} \\
\pi_{j, t} \\
i_{j, t}
\end{array}\right] } & =\left[\begin{array}{c}
\widehat{u}_{j, t} \\
\widehat{\pi}_{j, t} \\
\widehat{i}_{j, t}
\end{array}\right]+\left[\begin{array}{lll}
1 & 0 & 0 \\
0 & 1 & 0 \\
0 & 1 & 1
\end{array}\right] \cdot\left[\begin{array}{c}
X_{j, t}^{u} \\
X_{j, t}^{m} \\
X_{j, t}^{r}
\end{array}\right], \\
X_{j, t}^{s} & =X_{j, t-1}^{s}+x_{j, t}^{s},
\end{aligned}
$$

where $\widehat{u}_{j, t}, \widehat{\pi}_{j, t}$ and $\widehat{i}_{j, t}$ are the cyclical components of the unemployment, inflation, and policy rates, respectively; $X_{j, t}^{u}$ is the trend in the unemployment rate; $X_{j, t}^{m}$ is a common trend in inflation and policy rates, referred to as the monetary trend. We assume that these two trends follow simple random walk processes (Equation 4). We refer to the trend in policy rates above and beyond the monetary trend, $X_{j, t}^{r}$, as the real neutral interest rate.

Cyclical unemployment, inflation, and policy rates follow a vector autoregression of first order, VAR(1), subject to structural shocks. Specifically,

$$
\widehat{Y}_{j, t}=B \cdot \widehat{Y}_{j, t-1}+C \cdot Z_{j, t}, \quad \widehat{Y}_{j, t} \equiv\left[\begin{array}{lll}
\widehat{u}_{j, t} & \widehat{\pi}_{j, t} & \widehat{i}_{j, t}
\end{array}\right]^{\prime},
$$

where $Z_{j, t}$ is a vector with all shocks, including those to the stochastic trends: permanent

\footnotetext{
${ }^{16}$ Supporting our choice, Quast and Wolters (2020) argues that trends obtained by Hamilton (2018) still contain high-frequency noise because it does not cover typical business cycle frequencies evenly, muting short and amplifying medium-length cycles.

${ }^{17}$ For details on the data used by the state-space model, see Appendix C.1.
} 
unemployment rate shocks $x_{j, t}^{u}$; permanent monetary shocks $x_{j, t}^{m}$; changes in real neutral interest rates $x_{j, t}^{r}$; temporary monetary shocks $z_{j, t}^{p}$; temporary demand shocks $z_{j, t}^{d}$; and temporary supply shocks $z_{j, t}^{s} \cdot{ }^{18}$ For simplicity, we assume that $x_{j, t}^{u}, x_{j, t}^{m}, z_{j, t}^{p}$, and $z_{j, t}^{s}$ are independent and identically distributed with normal distributions, while $z_{j, t}^{d}$ follows an autoregressive process of order one, $\mathrm{AR}(1) .{ }^{19}$ We then identify these shocks through restrictions on the matrix $C$, later described in Section 3.2.

Motivated by Equation (2) of Section 2.1, we model changes in real neutral interest rates $x_{j, t}^{r}$ as depending on the net supply of safe assets and other observed data:

$$
x_{j, t}^{r}=\beta_{p t} \Delta p t_{j, t}+\beta_{w s} \Delta w s_{j, t}+\beta_{c y} \Delta c y_{t}+\beta_{s a} \Delta s a_{t}+\beta_{r o w} g_{j, t-1}+\epsilon_{j, t},
$$

where $\Delta p t_{j, t}$ is economy $j$ 's change in trend-productivity growth; $\Delta w s_{j, t}$ is economy $j$ 's change in the working-age share; $\Delta c y_{t}$ is the change in the trend convenience yield; $\Delta s a_{t}$ is the change in the net supply of safe assets; $\epsilon_{j, t}$ are shocks and account for unobserved determinants of neutral interest rates; ${ }^{20}$ and $g_{j, t-1}$ is our measure of global spillovers,

$$
g_{j, t-1}=\sum_{i \neq j} \omega_{i}^{j}\left(\beta_{p t} \Delta p t_{i, t-1}+\beta_{w s} \Delta w s_{i, t-1}\right)
$$

calculated as the trade-weighted $\left(\omega_{i}^{j}\right)$ rest-of-the-world's productivity and working-age share from economy $j$ 's perspective. Thus, by using this measure of global spillovers, we decomposes the contributions from productivity and demographics into economy-specific and rest-of-the-world components.

We assume that the determinants of neutral rates $\left(\Delta p t_{j, t}, \Delta w s_{j, t}, \Delta c y_{t}, \Delta s a_{t}\right)$ are unrelated to each other and to the cyclical state of their economies. This assumption is based on the idea that these variables represent slow-moving economic forces that are exogenous in our analysis, such as the demographic transition, technological evolution, and lasting regulatory reforms. Importantly, this assumption allows us to decompose changes in neutral rates as originated from each one of these determinants. In Section 4.7, we show that our results are robust to allowing the cyclical state of the economy to affect net safe assets.

\footnotetext{
${ }^{18}$ For simplicity, we specify the cyclical VAR, Equation (5), with only one lag. Results are very similar if we use two lags, as shown in Section 4.7.

${ }^{19} \mathrm{We}$ assume that the variance of each shock $\left(x_{j, t}^{m}, z_{j, t}^{p}, x_{j, t}^{u}, z_{j, t}^{d}, z_{j, t}^{s}\right)$ and the autocorrelation parameter of $z_{j, t}^{d}$ is the same across countries.

${ }^{20}$ For the sake of simplicity, we model $\epsilon_{j, t}$ as independent and identically distributed errors across time and countries, with the same variance across countries.
} 


\subsection{Identification of Shocks}

We impose the following identification assumptions on matrix $C$ of Equation (5):

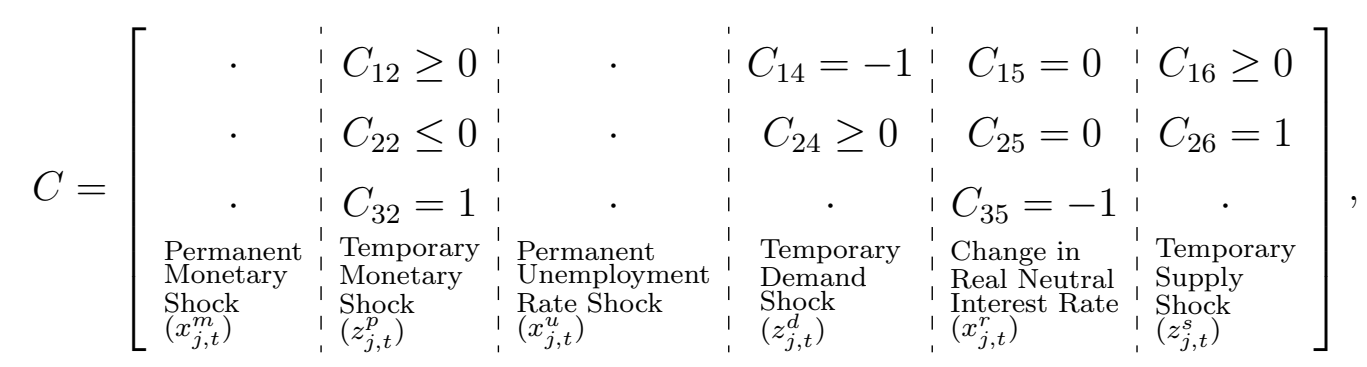

where "." represents the absence of sign restrictions. Because we estimate our model with a Bayesian approach, we impose restrictions on the prior distributions of these parameters. A normalized increase of 1 percent in the neutral real rate contemporaneously affects neither unemployment $\left(C_{15}=0\right)$ nor inflation $\left(C_{25}=0\right)$ rates, leaving the level of policy rates also unchanged $\left(C_{35}=-1\right) .{ }^{21}$ Priors for the effects of permanent monetary shocks are centered around (but do not impose) the idea that the level of unemployment $\left(\mathbb{E}\left(C_{1,1}\right)=0\right)$, inflation $\left(\mathbb{E}\left(C_{2,1}\right)=-1\right)$ and policy $\left(\mathbb{E}\left(C_{3,1}\right)=-1\right)$ rates are unchanged upon the shock impact. ${ }^{22}$ Permanent unemployment-rate shocks follow a similar assumption: $\mathbb{E}\left(C_{1,3}\right)=-1$, $\mathbb{E}\left(C_{2,3}\right)=0$, and $\mathbb{E}\left(C_{3,3}\right)=0$.

We then make the following assumptions about the stationary shocks. Temporary monetary shocks may contemporaneously increase the unemployment rate $\left(C_{12} \geq 0\right)$ and decrease inflation $\left(C_{22} \leq 0\right)$, with the increase in policy rates being normalized to $1\left(C_{32}=1\right)$. Temporary demand shocks contemporaneously decrease the unemployment rate $\left(C_{14}=-1\right)$ and may increase inflation $\left(C_{24} \geq 0\right)$, with the response of monetary policy $\left(C_{34}\right)$ left unrestricted. Lastly, temporary supply shocks increase inflation $\left(C_{26}=1\right)$ and may increase unemployment rates $\left(C_{26} \geq 0\right)$, with the response of policy rates $\left(C_{36}\right)$ left unrestricted.

\footnotetext{
${ }^{21}$ Suppose that the level of policy rates is unchanged $\left(\Delta i_{j, t}=0\right)$ after a change in the real neutral interest rate, $x_{j, t}^{r}=1$. Then, Equations (3)-(4) imply $\Delta i_{j, t}=\Delta \widehat{i}_{j, t}+x_{j, t}^{m}+x_{j, t}^{r}$, and thus $C_{35}=\Delta \widehat{i}_{j, t}=-1$.

${ }^{22}$ Arguments are similar to those used for changes in neutral real interest rates (footnote 21 ).
} 


\subsection{Estimation, Prior and Posteriors Distributions}

We close the model by stipulating relationships between model variables and observable variables. Specifically, from Equations (3) and (4) we have the following:

$$
\begin{aligned}
\Delta u_{j, t} & =\left(\widehat{u}_{j, t}-\widehat{u}_{j, t-1}\right)+x_{j, t}^{u} \\
\Delta r_{j, t} & \left.=\widehat{i}_{j, t}-\widehat{i}_{j, t-1}\right)-\left(\widehat{\pi}_{j, t}-\widehat{\pi}_{j, t-1}\right)+x_{j, t}^{r} \\
\Delta i_{j, t} & \left.=\widehat{i}_{j, t}-\widehat{i}_{j, t-1}\right)+x_{j, t}^{m}+x_{j, t}^{r} \\
\widehat{\pi}_{j, t} & =\pi_{j, t}-X_{j, t}^{m}
\end{aligned}
$$

where $r_{j, t}=i_{j, t}-\pi_{j, t}$ are real interest rates, and $\widehat{\pi}_{j, t}$ are the difference between inflation rates, $\pi_{j, t}$, and long-term inflation expectations, $X_{j, t}^{m}$ (data details in Appendix B.1). ${ }^{23}$ Model (3)-(11) admits a Kalman filter representation which we use to estimate it.

We estimate our model with Bayesian techniques. We use prior distributions for the model parameters and approximate the posterior distribution using a Metropolis Hastings algorithm to implement the Monte-Carlo Markov Chain method. We use 1.5 million draws of the posterior distribution to calculate our results, discarding the first $25 \%$ draws.

While our prior distributions are standard in the literature, our posterior distributions are informative, thus quantifying the importance of different drivers of neutral interest rates. Priors for the parameters related to these drivers (Table 1) are centered around zero, with the exception of the parameter related to global spillovers, which has a prior bounded between 0 and 1 with a large standard deviation. These priors formalize a hypothesis that (i) either neutral rates have not changed over time or (ii) the postulated neutral rate drivers do not account for the changes, with unobserved factors $\left(\epsilon_{j, t}\right.$ in Equation 6$)$ as the sole explanatory culprit. Nonetheless, the posterior distributions (Table 1) have medians that are statistically different from the medians of the priors. Moreover, standard deviations of the posteriors are also tighter than those from the respective priors. Details about prior and posterior distributions of all parameters of the model are in Appendix C.2.

\footnotetext{
${ }^{23}$ Long-term inflation expectations helps the model pin down a more realistic path for the monetary trend in our sample. In Section 4.7, an alternative estimation shows that the importance of safe assets supply to changes in neutral rates does not change if we exclude inflation expectations from the estimation.
} 
TABLE 1

Parameter Distributions: Drivers of Neutral Rates

\begin{tabular}{lllccccc}
\hline \hline \multirow{2}{*}{ Parameter } & & \multicolumn{3}{c}{ Prior Distribution } & & \multicolumn{2}{c}{ Posterior Distribution } \\
& Name & Distribution & Median & Std & & Median & Std \\
\hline$\beta_{s a}$ & Net Safe Assets & Normal & 0.00 & 0.08 & & 0.16 & 0.06 \\
$\beta_{p t}$ & Convenience Yield & Normal & 0.00 & 1.00 & & -2.17 & 0.84 \\
$\beta_{w s}$ & Woductivity & Normal & 0.00 & 0.50 & & 0.59 & 0.19 \\
$\beta_{\text {row }}$ & Global Spillovers & Beta & 0.00 & 0.25 & & 0.14 & 0.11 \\
\hline \hline
\end{tabular}

Note: The table shows statistics about prior and posterior distributions of selected parameters of the model. "Std" refers to standard deviation.

\subsection{Remarks About the Model Specification}

Our framework has several advantages relative to other approaches in the literature. We discuss below the motivations for some of our modelling choices.

We include in the estimation of our model many possible determinants of neutral rates. This approach allows us to simultaneously evaluate many well-cited drivers of neutral rates in the literature, such as demographics, productivity, and the convenience yield, and to account for the statistical uncertainty around the relevance of these drivers. Other studies either focus on a restricted set of neutral rate determinants or rely on correlations between these determinants and ex-post calculated neutral interest rates. ${ }^{24}$

We use a large cross-country dataset on productivity to measure the relevance of longrun drivers of economic growth to neutral rates. By exploiting these rich data, we can avoid (i) restricting ourselves to a small number of variables, and (ii) imposing identification assumptions on the econometric framework to estimate trend GDP growth, such as in the groundbreaking work of Laubach and Williams (2003). ${ }^{25}$ We then use the unemployment rate to measure the state of the economy in the business cycle and ensure that the main identification hypothesis of neutral interest rates is satisfied-real short-term interest rates consistent with both economic activity and inflation at their trend.

We allow trend variables to affect the cyclical state of our economies (columns 1, 3 and 5 in matrix $C$ of Equation 5). We do so to be consistent with the empirical evidence

\footnotetext{
${ }^{24}$ For instance, see Del Negro et al. (2019), Lunsford and West (2019), Hamilton et al. (2016).

${ }^{25}$ After the contribution of Laubach and Williams (2003), many papers follow this strategy, such as Holston et al. (2017), Jorda and Taylor (2019), Rachel and Summers (2019), Kiley (2020) among others.
} 
showing that shocks to trends in inflation and economic growth, such as productivity, have important business cycle implications. ${ }^{26}$ Our goal is to account for this feedback between trends and cycles when we estimate the trend in the real interest rate: the neutral rate.

We allow cross-country spillovers in the estimation of neutral rates (Equations (6) and (7)). This assumption is consistent with predictions from textbook models that investor decisions push international interest rates to co-move, as long as there is cross-country capital mobility (see for example Obstfeld (2020) and Clarida (2019)). Indeed, other papers find sizable cross-country co-movement in neutral rates. ${ }^{27}$ Our modeling of global spillovers allows us to split the contributions of productivity and demographics to the neutral rate of every country into two components: the country-specific and the rest-of-the-world. Because of the trade-weighted aggregation, the rest-of-the-world components behave very similarly across countries, thus capturing a "world" co-movement of neutral rates while retaining the economic and geographical interpretation. Moreover, our modelling allows for developments in productivity and demographics of one economy to affect other economies as well. In contrast, approaches based on common factors achieve a similar economy-specific/world decomposition, but they lose the economic interpretation (the common factor mixes the geographical origin of the economic drivers) and do not capture cross-countries spillovers.

In Section 4.7, we consider many alternative model specifications, and show that the supply of safe assets remains as an important driver of neutral rates in all of these models.

\section{Neutral Interest Rates of Advanced Economies}

Our main finding is that the net supply of safe assets is a major determinant of neutral rates around the world. While exchange reserve accumulation by foreign governments ("global savings glut") has pushed down neutral rates, higher safe assets availability has pushed them up. Finally, global spillovers are also important for the dynamics of neutral rates.

\footnotetext{
${ }^{26}$ See Ramey (2016) for literature review productivity shocks. For more details on shocks to inflation trend, see De Michelis and Iacoviello (2016), Uribe (2021), and Schmitt-Grohé and Uribe (2018).

${ }^{27}$ In many cases, these results are estimated either on neutral rates from single-country models (e.g., Holston et al. (2017)) or cross-country models with global factors (e.g., Del Negro et al. (2019)) .
} 
FiguRE 4

Neutral Real Interest Rates Across Advanced Economies

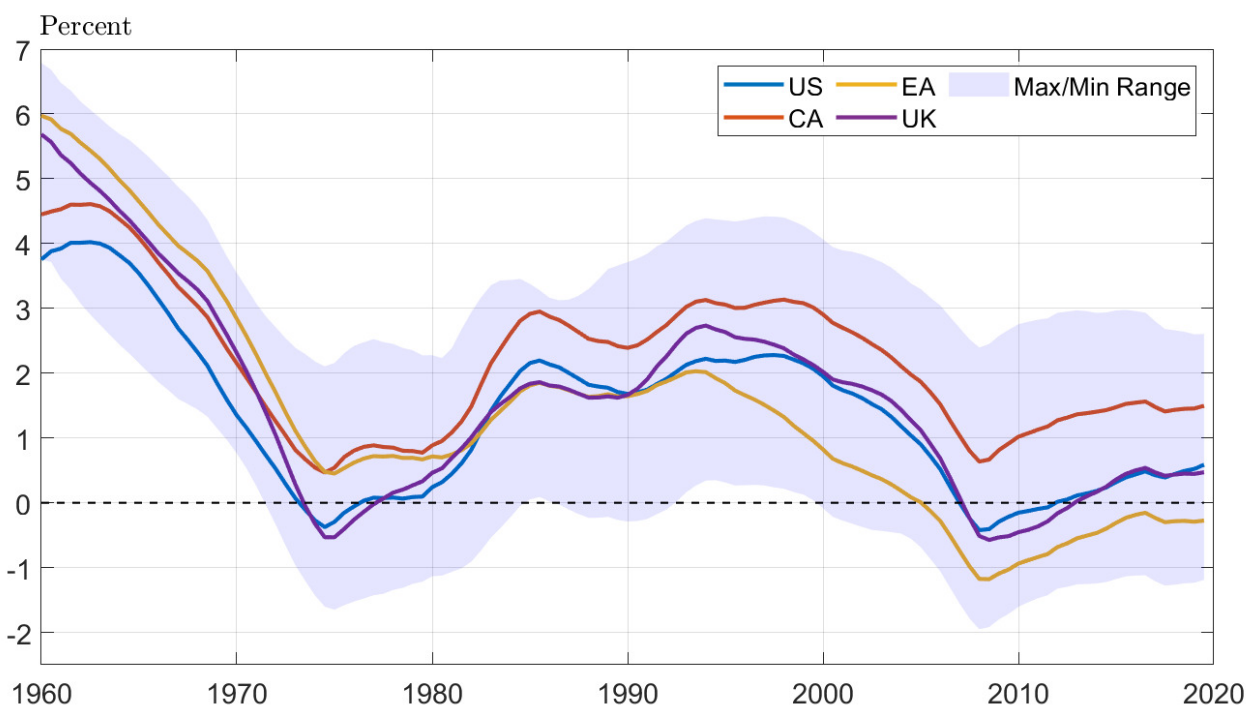

NotE: The figure shows neutral interest rates estimated by the model of Section 3 using the median values of the posterior distribution of parameters. Economies are abbreviated as US for the United States, CA for Canada, EA for the euro area, and UK for the United Kingdom.

\subsection{Two Waves of Declining Neutral Rates: 1960-70s and 2000s}

Our model points to two waves of decline in neutral interest rates between 1960 and 2019 (Figure 4). In the first wave, from 1960 to the mid-1970s, neutral rates decreased considerably, with euro-area rates declining from $6 \%$ to $0.5 \%$, and U.S. rates going from $4 \%$ to $-0.4 \%$. In the early-1980s, neutral rates rebounded, experiencing some fluctuations until the late-1990s. After this period, a second wave of decline in neutral rates started again. Neutral rates then reached new troughs in 2008, after which many countries saw a rebound in their neutral rates. In 2019H2, our model estimates that Canada's neutral real interest rate was $1.5 \%$, the U.S. $0.6 \%$, the United Kingdom's $0.5 \%$, and the euro area's $-0.3 \% .^{28}$

\subsection{Safe Assets as an Important Driver of Neutral Real Rates}

Our model finds net safe assets as an important driver of neutral rates through three different manners. First, the elasticity of neutral real rates to net safe assets $\left(\beta_{s a}\right)$ is not only statistically different from zero (Table 1), but also economically significant. The median value of the posterior distribution of $\beta_{s a}$ is 0.16 , meaning that a decline of 10 percentage points in the net safe asset supply pushes down neutral rates by 1.6 percentage points.

\footnotetext{
${ }^{28}$ In Appendix C, we show the calculated time-varying trends in inflation and unemployment rates.
} 
FiguRE 5

Historical Decomposition of Changes in Neutral Real Rates

(A) United States

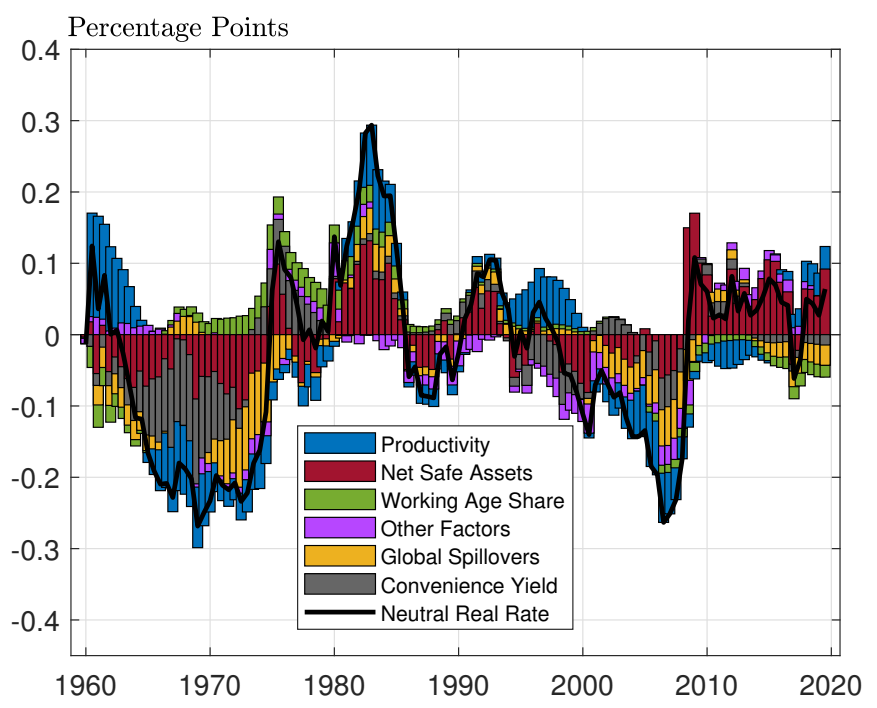

(c) Euro Area

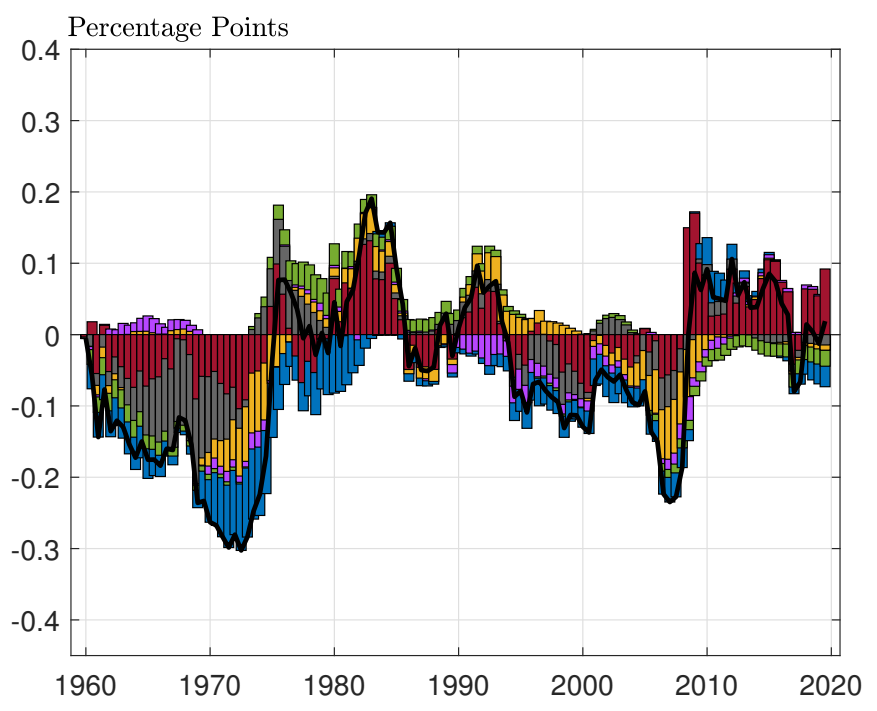

(в) Canada

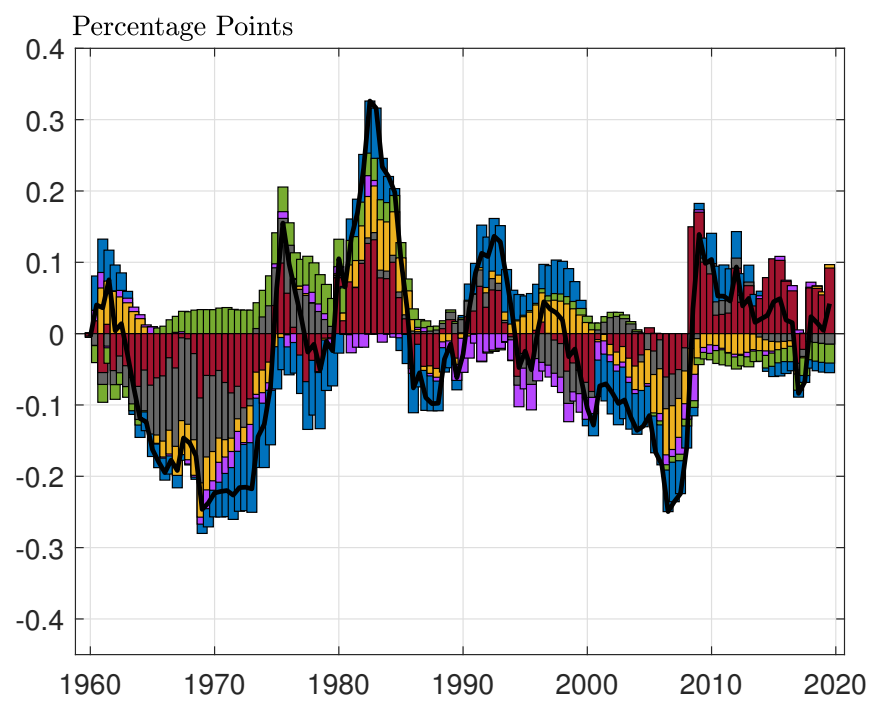

(D) United Kingdom

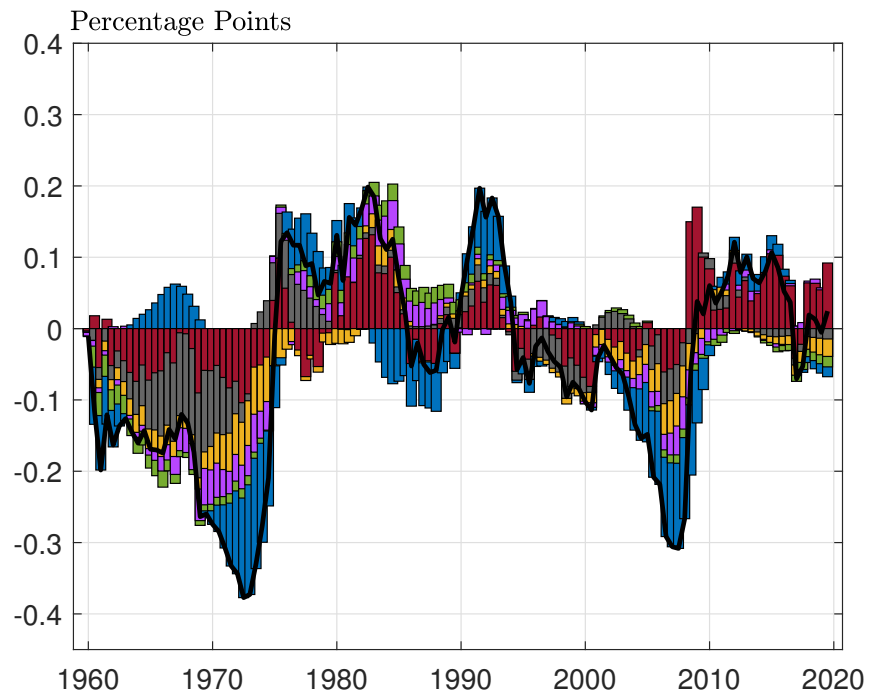

Note: The figure shows the historical decomposition of changes in real neutral interest rates (black line) using median values of the posterior distribution of parameters. At each period, neutral rates are driven by changes in the following variables: trend-productivity growth, denoted by "Productivity" (blue bars); net supply of safe assets, denoted by "Net Safe Assets" (red bars); working-age population share, denoted by "Working-Age Share" (green bars); other unobserved factors, denoted by "Other Factors" (pink bars); trend convenience yield, denoted by "Convenience Yield" (gray bars); and "Global Spillovers" (yellow bars), where the latter is defined in Equation (7). 
TABLE 2

Variance Decomposition: Changes in Neutral Rates (Percent)

\begin{tabular}{lcccccccccccc}
\hline \hline & & \multicolumn{11}{c}{ Countries } \\
Shocks & AL & CA & DN & EA & JA & NO & NZ & SD & SZ & UK & US & AVE \\
\hline Net Safe Assets & 38 & 39 & 40 & 51 & 23 & 34 & 26 & 32 & 40 & 39 & 41 & 37 \\
Convenience Yield & 18 & 18 & 19 & 24 & 11 & 16 & 12 & 15 & 19 & 18 & 19 & 17 \\
Productivity & 27 & 23 & 32 & 12 & 57 & 43 & 54 & 47 & 32 & 34 & 29 & 35 \\
Working-Age Share $^{2}$ & 2 & 5 & 3 & 4 & 3 & 2 & 2 & 1 & 2 & 2 & 3 & 3 \\
Global Spillovers $^{1}$ & 12 & 12 & 3 & 5 & 4 & 2 & 4 & 3 & 4 & 4 & 5 & 5 \\
Other Factors $^{2}$ & 3 & 3 & 3 & 4 & 2 & 3 & 2 & 2 & 3 & 3 & 3 & 3 \\
\hline \hline
\end{tabular}

Note: The table shows the variance decomposition of changes in real neutral interest rates at the median values of the posterior distribution of parameters. Percentages might not add to 100 because of rounding. Names of economies are abbreviated as AL for Australia, CA for Canada, DN for Denmark, EA for the euro area, JA for Japan, NO for Norway, NZ for New Zealand, SD for Sweden, SZ for Switzerland, UK for the United Kingdom, and US for the United States. AVE stands for the average across economies. "Global Spillovers" is defined in equation (7). "Other Factors" represent the unobserved factors proxied by the shock $\epsilon_{j, t}$ in equation (6).

For reference, net safe assets decreased by about 5 percentage points of world GDP from 1994H1 to 2007H2 (Figure 3d). Second, net safe assets play a relevant role in the variability of neutral rates over the sample period. Specifically, the variance decomposition of neutral real rates (Table 2) shows that fluctuations in net safe assets account for an average of about $37 \%$ of the variation of neutral rates across advanced economies. Third, the historical decomposition of neutral rates (Figure 5) shows that net supply of safe assets (red bars) was an important driver in many historical periods: the first wave of decline from 1960 to the mid-1970s; the rebound of the early 1980s; the steady decline during the 2000s; and the gradual increase after 2008, when higher net safe assets counteracted the downward pressure from other factors, such as demographics and the convenience yield.

To provide further evidence about the importance of net safe assets to neutral interest rates, we analyze the effects of omitting it from the estimation of our model. Specifically, we estimate an alternative specification imposing $\beta_{s a}=0$. This specification relies more on other determinants of neutral rates, yielding results closer to those seen in other papers. For instance, the contributions of the convenience yield and trend-productivity to the variance decomposition of neutral rates increase to an average of $35 \%$ and $52 \%$, respectively, across advanced economies. ${ }^{29}$ However, the overall fit of the model decreases, with this alternative

\footnotetext{
${ }^{29}$ The contribution of working-age share is $2 \%$, while the one from global spillovers is $7 \%$ and the one
} 
FiguRE 6

Safe Assets Availability and U.S. Neutral Real Rates

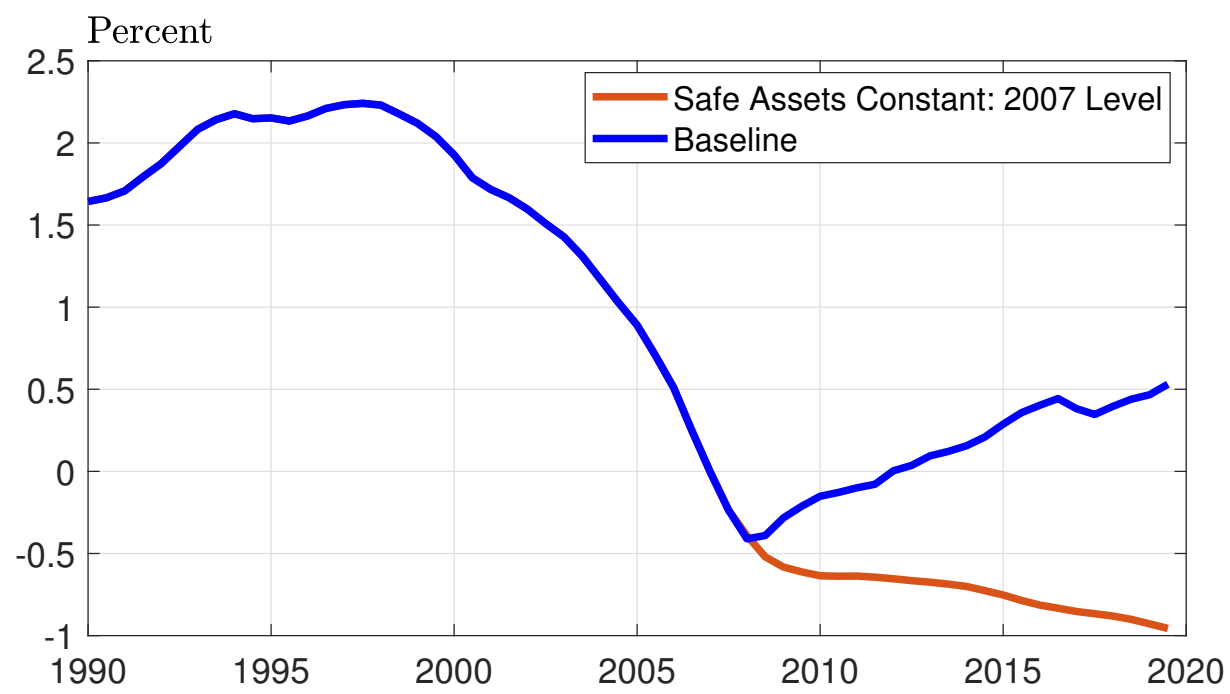

Note: The figure shows real neutral interest rates for the baseline model of Section 3 (blue line) and under the counterfactual assumption that level of net supply of safe assets (as percentage of world GDP) stays constant at the $2007 \mathrm{H} 2$ level from this period onward (black line). We calculate neutral rates using median values of the posterior distribution of parameters.

specification having a marginal likelihood 4.4 log-points lower than our benchmark model. These results are consistent with our measure of safe assets having an explanatory power on neutral rates that is not contained in the other determinants of these rates.

\subsection{Safe Assets Availability Pushed Up Neutral Rates Since 2008}

We find that higher safe assets availability since 2008 has pushed up neutral interest rates. We estimate this effect by implementing a counterfactual exercise under which we suppose that net safe assets as a percentage of world GDP remains constant at the 2007H2 level from this date until the end of the sample. We focus on this period because of the continued increase of U.S. public debt after the Great Recession. Indeed, Figure 6 shows that this increased availability of safe assets has prevented U.S. neutral rates from continuing to fall after 2008 due to factors such as a higher convenience yield, domestic demographics, and global spillovers of other countries' demographics and productivity. Moreover, we find that the effect of a larger net safe asset supply has been sizable: neutral real interest are about 1.5 percentage points higher than what it would have been if safe assets supply stayed from other factors is $4 \%$. 
FiguRe 7

Foreign Exchange Reserves and U.S. Neutral Real Rates

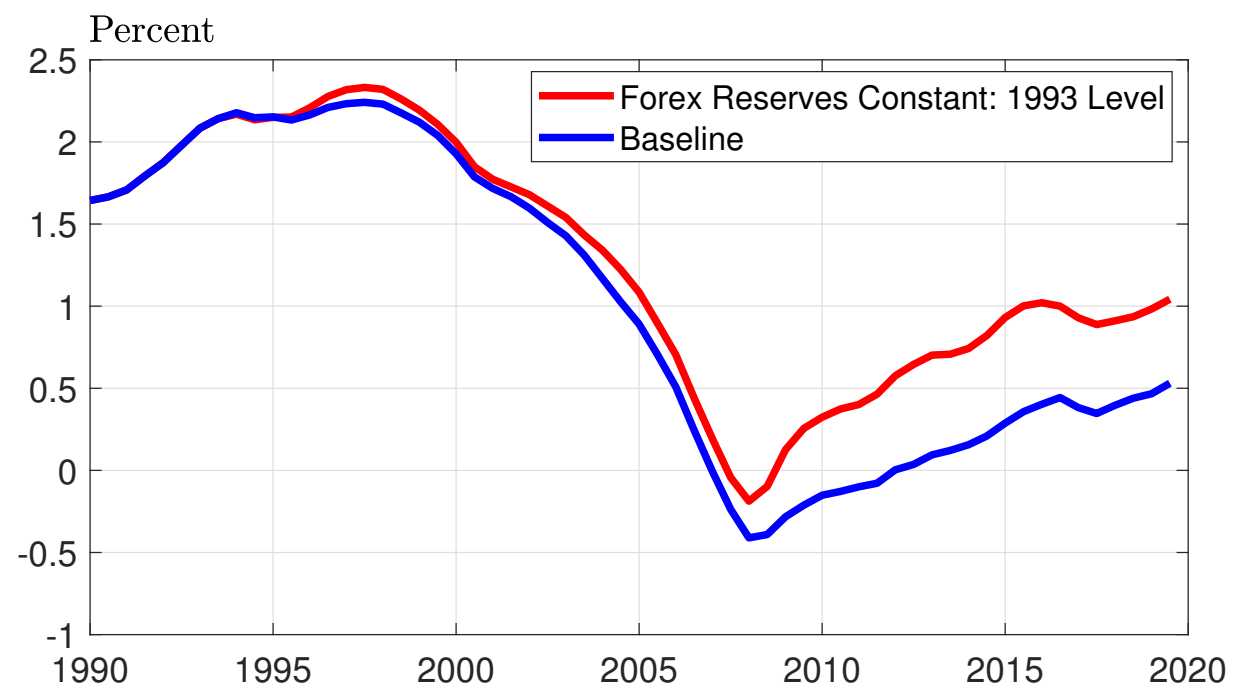

Note: The figure shows real neutral interest rates for the baseline model of Section 3 (blue line) and under the counterfactual assumption that the level of exchange reserves held by foreign governments stays constant (as percentage of world GDP) at the 1993H2 level from this period onward (red line). We calculate neutral rates using median values of the posterior distribution of parameters.

constant as a percentage of world GDP since 2008.

\subsection{Foreign Exchange Reserves Have Pushed Down Neutral Rates}

Our model estimates that foreign exchange reserve accumulation has pushed down neutral rates, especially after 2008. To evaluate this claim, we conduct a counterfactual exercise in which we feed the model a path of net safe assets that does not exclude the accumulation of international exchange reserves by foreign governments. The rationale for this exercise is to quantify the upward pressure on neutral rates if market participants had to absorb the amount of safe assets that were accumulated through government policies. To simplify, we suppose that foreign official (government) holdings of US Treasuries stays constant (as a percentage of world GDP) at the 1993H2 level from this period until the end of the sample. This is the period in which the series of net supply of safe assets (red line in Figure 2) and marketable debt (green line in Figure 2) diverge most prominently.

Figure 7 shows the paths of estimated neutral rates under the baseline model (blue line) and using the counterfactual series of net safe assets (red line). By the end of 2008, foreign reserve accumulation had pushed down neutral rates by about 30 basis points. Moreover, 
despite the increasing levels of debt after the 2008 crisis, the continued accumulation of foreign exchange reserves exerted downward pressure on neutral rates, with the negative contribution reaching 65 basis points in 2015. After this period, the pace of reserve accumulation decreased, and so did its negative effect on neutral rates. In 2019H2, foreign reserves were weighing down neutral rates by 50 basis points.

\subsection{Global Spillovers: Neutral Rates and their Co-Movement}

Global spillovers of economy-specific developments in trend-productivity and demographics have played a significant role in explaining the trajectories of neutral rates (yellow bars in Figure 5). For example, the cumulative effect of these global spillovers on neutral rates for the 2000-2019 period is negative 85 basis points for the U.S. and negative 88 basis points for Canada. Underlying this downward pressure from global spillovers are the productivity slowdown of the 2000s and the acceleration of the demographic transition that started around the same period (Figures 3a and 3b). Additionally, global spillovers have moderate contributions to the variance decomposition of neutral rates (Table 2), since these spillovers evolve very gradually over time.

We find that accounting for global spillovers prevents a researcher from over-emphasizing global determinants of neutral rates. To reach this result, we first estimate an alternative specification imposing $\beta_{\text {row }}=0$, which yields a marginal likelihood 3.8 log-points lower than the benchmark model. Then, we compare the variance decomposition of these two models. We find that, under the alternative specification, the contributions of global determinants (net safe assets and the convenience yield) increase by 10 percentage points. This increase is higher than the 5 percentage points attributed to global spillovers in the benchmark model (Table 2) because the contribution of economy-specific determinants (productivity and demographics) also decreases by 5 percentage points. ${ }^{30}$ In sum, the inclusion of global spillovers in the model allows it to de-emphasize global determinants and enhance crosscountry relationships that have not been estimated in other models.

Global spillovers are also an important factor explaining the global co-movement of neutral rates. To reach this conclusion, it is useful to think about three potential forces explaining this co-movement: (i) global determinants affecting all countries in the same

\footnotetext{
${ }^{30}$ Under the specification with $\beta_{\text {row }}=0$, the cross-country average contributions to the variance decomposition of neutral interest rates are as follows: $40 \%$ from net safe assets, $25 \%$ for the convenience yield, $31 \%$ for productivity, $1 \%$ for working-age share, and $3 \%$ for other factors.
} 
TABLE 3

Average Pair-Wise Correlations of Changes in Neutral Rates

\begin{tabular}{c|cccc}
\hline \hline \multirow{3}{*}{$\begin{array}{c}\text { Neutral } \\
\text { Rates }\end{array}$} & \multicolumn{4}{|c}{ Counterfactual: Only Each Determinant } \\
\cline { 2 - 5 } & $\begin{array}{c}\text { Economy } \\
\text { Specific }\end{array}$ & $\begin{array}{c}\text { Global } \\
\text { Spillovers }\end{array}$ & $\begin{array}{c}\text { Net Safe } \\
\text { Assets }\end{array}$ & $\begin{array}{c}\text { Convenience } \\
\text { Yield }\end{array}$ \\
\hline 0.83 & 0.34 & 0.77 & 1 & 1 \\
\hline \hline
\end{tabular}

Note: The table shows average pair-wise correlations between countries' changes in neutral rates using median values of the posterior distributions of parameters. "Neutral Rates" column shows the average pair-wise correlation of estimated neutral rates. Remaining columns show the correlations under counterfactual assumptions that only certain drivers move neutral rates: "Country Specific" includes productivity, demographics and unobserved factors $\left(\epsilon_{j, t}\right)$; "Global Spillovers" includes the term of equation (7); "Net Safe Assets" includes net safe asset supply; "Convenience Yield" includes the trend convenience yield.

way, such as the net safe assets and the convenience yield; (ii) a synchronized cross-country behavior in economy-specific determinants (i.e., trend productivity and demographics); and (iii) global spillovers of these economy-specific determinants.

We then calculate the amount of co-movement implied by each one of these three types of drivers above, finding a sizable co-movement implied by global spillovers (Table 3). We use a simple measure of co-movement: the average pair-wise correlation between economies' changes in neutral rates. To establish a benchmark, we use the baseline series of changes in neutral rates and find an average pair-wise correlation of 0.83 . Then, to assess the role of each neutral rate driver, we calculate average pair-wise correlations using only the contributions of each driver to neutral rates. We then find an average correlation of 0.77 from the contributions of global spillovers of productivity and demographics, a number relatively close to the benchmark calculation. In contrast, the average correlation from the contributions from economy-specific determinants (trend productivity, demographics and idiosyncratic unobserved factors) is 0.34 . Finally, the average correlations from the contributions of net safe assets and convenience yield are 1 because these variables affect all economies' neutral rates in the same way.

\subsection{Other Drivers of Neutral Rates Are Also Important}

Trend-productivity growth plays a prominent role in explaining neutral real interest rates. First, the estimated median elasticity of neutral rates to trend-productivity $\left(\beta_{p t}\right)$ is 0.59 , meaning that a decrease in trend-productivity growth of 1 percentage point lowers neutral 
rates by 0.59 percentage point. Second, the contribution of trend-productivity to the variance of neutral rates is quite significant (Table 2): It accounts for an average of $35 \%$ of the changes in neutral rates across the 11 economies. Third, changes in trend productivity were important in several historical periods (blue bars in Figure 5), such as the productivity slowdown of the 1970s and 2000s.

We also estimate that demographics have played a relevant role in determining neutral rates. Our model finds that a lower working-age share of the population pushes down neutral rates (Table 1). Thus, the decline in working-age shares since the early-2000s (Figure 3b) has been a drag on neutral rates (green bars in Figure 5). For instance, the cumulative effect on neutral rates of the 2000-2019 working-age share decline is negative 34 basis points for the U.S. and negative 42 basis points for the euro area.

Finally, the convenience yield also acts as an important driver of neutral rates. It accounts for an average of $17 \%$ of the variance of neutral rates across countries (Table 2), with important contributions in the 1960s and 1970s (gray bars in Figure 5). More recently, the gradual rise in the trend convenience yield in the 2000-2019 period has pushed down neutral rates, with a negative contribution of 24 basis points in the U.S. These results are consistent with demand-for-safe-assets factors beyond demographics, such as regulatory changes for financial institutions and increasing risk aversion (e.g., higher macroeconomic risk or lower tolerance of agents to it).

\subsection{Alternative Specifications}

In this section, we show that the importance of net safe asset supply as a determinant of neutral rates is robust to a vast number of alternative specifications to our model. To focus on the main point of this paper, we show that the posterior distribution of the elasticity of neutral rates to net safe assets $\left(\beta_{s a}\right)$ is relatively unchanged under many different specifications (Figure 8). To reach this conclusion, we consider the following models: using two lags in Equation (5); substituting working-age share by birth rate as the demographic variable; using the net supply of safe assets of advanced economies (Figure 2b) instead of our baseline measure; allowing cyclical U.S. unemployment, inflation, and policy rates to affect the net supply of safe assets; calculating net supply of safe assets by also excluding Treasury holdings of the Federal Reserve; using the filter from Hamilton (2018) to obtain the trends of productivity growth and convenience yield, instead of the HP-filter with high 


\section{FiguRE 8}

Elasticity to Safe Assets $\left(\beta_{s a}\right)$ in Alternative Models

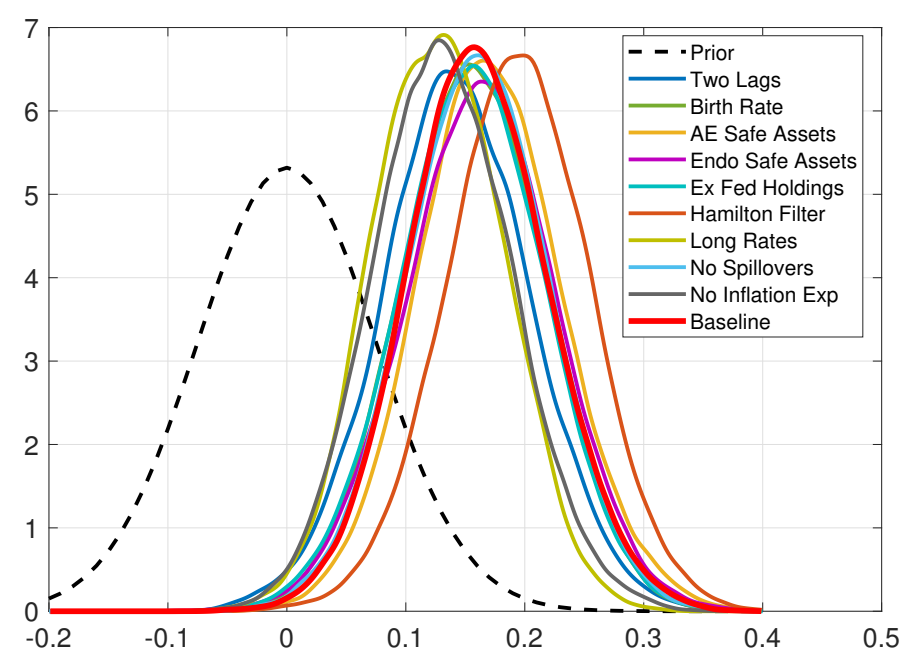

Note: Figure 8 shows the prior density distribution of $\beta_{s a}$ (dashed line) and its posterior distributions calculated under many different specifications of the model of Section 3.

smoothing values; including 10-year interest rates in the estimation of the model in addition to the unemployment, inflation, and policy rates; turning off global spillovers $\left(\beta_{\text {row }}=0\right)$; and excluding data on long-term inflation expectations from the estimation. We provide a detailed discussion about these alternative model specifications in Appendix D.

\section{Conclusion}

This paper focuses on the demand-vs.-supply of safe assets to study global neutral interest rates. We propose a measure of the global supply of sovereign safe assets that takes into account governments' accumulation of international exchange reserves in sovereign safe assets. We then use this measure to estimate neutral interest rates from 1960 to 2019 for a panel of 11 advanced economies. We find that the supply of safe assets is a major driver of global neutral rates, even after controlling for many other factors. We estimate that, after 2008, the increasing availability of safe assets has prevented neutral rates from continuing their previous decline. We also evaluate the "global savings glut" hypothesis proposed by Bernanke (2005) and find that the global accumulation of international reserves contributed to a decline of up to 65 basis points in neutral rates. Finally, we find that economies' neutral rates are subject to important global spillovers from developments in other economies, with these spillovers explaining both the trajectories and co-movement of neutral rates. 
We see two important implications from our results. First, some researchers have argued that the costs of high public debt may not be as large as previously anticipated for many advanced economies because their interest rates have been lower than their nominal GDP growth rate (Blanchard, 2019). However, it is also important to determine the reasons why interest rates have been low and how fiscal expansions could affect interest rates. Our paper contributes to this debate by measuring how increasing public safe debt may drive up interest rates. Second, given this paper's evidence supporting a demand-vs.-supply-ofsafe-assets determination of neutral rates, it could be a promising avenue of research to further investigate demand-shifters of the market for safe assets. For instance, one could re-interpret traditional determinants of neutral rates as demand-shifters. Population aging may imply a larger portfolio allocation in safe assets, as older people may hold less-risky assets in their retirement savings, leading to a higher demand for safe assets and, then, lower neutral interest rates. ${ }^{31}$ Finally, regulations requiring financial firms to hold (i) more capital per risky asset, and (ii) more high-quality liquid assets may also lead to a higher demand for safe assets.

\footnotetext{
${ }^{31}$ Population aging, for example, increases the demand for safe assets through its impact on the assets of pension funds and their specific regulatory rules, as shown by Greenwood and Vissing-Jorgensen (2018).
} 


\section{References}

Aksoy, Yunus, Henrique S. Basso, Ron P. Smith, and Tobias Grasl, "Demographic Structure and Macroeconomic Trends," American Economic Journal: Macroeconomics, 2019, 11 (1), 193-222.

Alekasir, Keyvan H, Nikoloz Anasashvili, Matias Antonio, Philip Dongsoo Hong, Daniela MH Klingebiel, Bernard Murira-Njogu, Guilherme Henrique Pereira Alves, Marco Antonio, Marco Antonio Ruiz Gil, Alexander Elliot Slater et al., "Inaugural RAMP survey on the reserve management practices of Central banks: Results and observations," Technical Report, The World Bank 2019.

Bergeaud, Antonin, Gilbert Cette, and Rémy Lecat, "Productivity trends in advanced countries between 1890 and 2012," Review of Income and Wealth, 2016, 62 (3), $420-444$.

Bernanke, Ben, "The Global Savings Glut and the U.S. Current Account Deficit," 2005. Sandridge Lecture, Virginal Economic Association.

Bertaut, Carol and Ruth Judson, "Estimating U.S. Cross-Border Securities Positions: New Data and New Methods," International Finance Discussion Papers, 2014, 1113. Board of Governors of the Federal Reserve System (U.S.).

Blanchard, Olivier, "Public debt and low interest rates," American Economic Review, 2019, 109 (4), 1197-1229.

Boyarchenko, Nina, Andreas Fuster, and David O Lucca, "Understanding mortgage spreads," The Review of Financial Studies, 2019, 32 (10), 3799-3850.

Brand, Claus, Marcin Bielecki, and Adrian Penalver, "The Natural Rate of Interest: Estimates, Drivers, and Challenges to Monetary Policy," Occasional Paper Series, 2018, 21\%. European Central Bank.

Caballero, Ricardo and Emmanuel Farhi, "The Safety Trap," Review of Economic Studies, 2018, 85 (1), 223-274.

_ , , and Pierre-Olivier Gourinchas, "Safe Asset Scarcity and Aggregate Demand," American Economic Review Papers and Proceedings, 2016, 106 (5), 513-518. 
_ , _, and _ , "The Safe Assets Conundrum," Journal of Economic Perspectives, 2017, $31(3), 29-46$.

_ , _, and _ , "Global Imbalances and Policy Wars at the Zero Lower Bound," Review of Economic Studies, 2021, Forthcoming.

Carvalho, Carlos, Andrea Ferrero, and Fernanda Nechio, "Demographics and Real Interest Rates:Inspecting the Mechanism," European Economic Review, 2016, 88 (C), 208-226.

Clarida, Richard, "The Global Factor in Neutral Policy Rates: Some Implications for Exchange Rates, Monetary Policy, and Policy Coordination," International Finance, 2019, 22 (1), 1-18.

Ellison, Martin and Andrew Scott, "Managing the UK National Debt 16942018," American Economic Journal: Macroeconomics, 2020, 12 (3), 227-257.

Farhi, Emmanuel and Francois Gourio, "Accounting for Macro-Finance Trends: Market Power, Intangibles, and Risk Premia," Brookings Papers on Economic Activity, 2018, 2018 (2), 147-250.

Gagnon, Etienne, Benjamin K. Johannsen, and David Lopez-Salido, "Understanding the New Normal: The Role of Demographics," Finance and Economics Discussion Series, 2016, 2016-080. Board of Governors of the Federal Reserve System (U.S.).

Gilchrist, Simon and Egon Zakrajšek, "Credit spreads and business cycle fluctuations," American Economic Review, 2012, 102 (4), 1692-1720.

Glick, Reuven, "R* and the Global Economy," Journal of International Money and Finance, 2020, $102(\mathrm{C}), 1-20$.

Gomme, Paul, B. Ravikumar, and Peter Rupert, "The Return to Capital and the Business Cycle," Review of Economic Dynamics, 2011, 14 (2), 262-278.

Gorton, Gary and Guillermo Ordonez, "The Supply and Demand for Safe Assets," NBER Working Paper, 2020, 18732.

_ , Stefan Lewellen, and Andrew Metrick, "The Safe-Asset Share," American Economic Review: Papers $\&$ Proceedings, 2012, 102 (3), 101-106. 
Gourinchas, Pierre-Olivier, "The Dollar Hegemon? Evidence and Implications for Policy Makers," in "6th Asian Monetary Policy Forum" 2019.

- and Olivier Jeanne, "The Allocation Puzzle," Review of Economic Studies, 2013, 80 (4), 14841515.

_, Helene Rey, and Maxime Sauzet, "The International Monetary and Financial System," Annual Review of Economics, 2019, 11, 859-893.

Greenwood, Robin and Annette Vissing-Jorgensen, "The Impact of Pensions and Insurance on Global Yield Curves," 2018. Unpublished.

Gürkaynak, Refet S, Brian Sack, and Jonathan H Wright, "The US Treasury yield curve: 1961 to the present," Journal of monetary Economics, 2007, 54 (8), 2291-2304.

Hamilton, James, "Why You Should Never Use the Hodrick-Prescott Filter," Review of Economics and Statistics, 2018, 100 (5), 831-843.

_ , Ethan Harris, Jan Hatzius, and Kenneth West, "The Equilibrium Funds Rate: Past, Present, and Future," IMF Economic Review, 2016, 64 (4), 660-707.

He, Zhiguo, Arvind Krishnamurthy, and Konstantin Milbrad, "A Model of Safe Asset Determination," American Economic Review, 2019, 109 (4), 1230-1262.

Hodrick, Robert J., "An Exploration of Trend-Cycle Decomposition Methodologies in Simulated Data," NBER Working Paper, 2020, 26750.

Holston, Kathryn, Thomas Laubach, and John C Williams, "Measuring the Natural Rate of Interest: International Trends and Determinants," Journal of International Economics, 2017, 108 (S1), S59-S75.

Hooper, Peter, Frederic S Mishkin, and Amir Sufi, "Prospects for Inflation in a High Pressure Economy: Is the Phillips Curve Dead or is It Just Hibernating?," NBER Working Paper, 2019, 25792.

Ilzetzki, Ethan, Carmen M. Reinhart, and Kenneth S. Rogoff, "Why is the Euro Punching Below its Weight?," 2019. Unpublished. 
Jones, Bradley, "Central Bank Reserve Management and International Financial StabilitySome Post-Crisis Reflections," IMF Working Paper, 2018, WP/18/31.

Jorda, Oscar and Alan M. Taylor, "Riders on the Storm," Jackson Hole Symposium Proceedings, 2019.

_ , Katharina Knoll, Dmitry Kuvshinov, Moritz Schularick, and Alan M. Taylor, "A Model of Safe Asset Determination," Quarterly Journal of Economics, 2019, 134 (3), 12251298 .

Kiley, Michael, "The Global Equilibrium Real Interest Rate: Concepts, Estimates,and Challenges.," Finance and Economics Discussion Series, 2019, 2019-076. Board of Governors of the Federal Reserve System (U.S.).

_ , "What Can the Data Tell Us About the Equilibrium Real Interest Rate?," International Journal of Central Banking, 2020, 16 (3), 181-209.

Krishnamurthy, Arvind and Annette Vissing-Jorgensen, "The Aggregate Demand for Treasury Debt," Journal of Political Economy, 2012, 120 (2), 233-267.

Krueger, Dirk and Alexander Ludwig, "On the Consequences of Demographic Change for Rates of Returns to Capital, and the Distribution of Wealth and Welfare," Journal of Monetary Economics, 2007, 54 (1), 49-87.

Laubach, Thomas and John C. Williams, "Measuring the Natural Rate of Interest," The Review of Economics and Statistics, 2003, 85 (4), 1063-1070.

Lunsford, Kurt G. and Kenneth D. West, "Some Evidence on Secular Drivers of U.S. Safe Real Rates," American Economic Journal: Macroeconomics, 2019, 11 (4), 113-139.

Michelis, Andrea De and Matteo Iacoviello, "Raising an inflation target: The Japanese experience with Abenomics," European Economic Review, 2016, 88, 67-87.

Negro, Marco Del, Domenico Giannone, Marc P. Giannoni, and Andrea Tambalotti, "Global Trends in Interest Rates," Journal of International Economics, 2019, 118 (C), 248-262.

Obstfeld, Maurice, "Global Dimensions of U.S. Monetary Policy.," International Journal of Central Banking, 2020, 16 (1), 73-132. 
Paoli, Bianca De and Pawel Zabczyk, "Cyclical risk aversion, precautionary saving, and monetary policy," Journal of Money, Credit and Banking, 2013, 45 (1), 1-36.

Pascal, Golec and Enrico Perotti, "Safe Assets: A Review," Working Paper Series, 2017, 2035. European Central Bank.

Quast, Josefine and Maik H. Wolters, "Reliable Real-Time Output Gap Estimates Based on a Modified Hamilton Filter," Journal of Business 86 Economic Statistics, 2020, Forthcoming.

Rachel, Lukasz and Lawrence Summers, "On Secular Stagnation in the Industrialized World," Brookings Papers on Economic Activity, 2019, 2019 (1), 1-76.

Ramey, Valerie A, "Macroeconomic shocks and their propagation," in "Handbook of macroeconomics," Vol. 2, Elsevier, 2016, pp. 71-162.

Reis, Ricardo, "The Constraint on Public Debt when $r<g$ but $g<m$," 2020. Unpublished.

Schmitt-Grohé, Stephanie and Martín Uribe, "Exchange rates and uncovered interest differentials: The role of permanent monetary shocks," NBER Working Paper, 2018, 25380.

Uribe, Martín, "The Neo-Fisher Effect: Econometric Evidence from Empirical and Optimizing Models," American Economic Journal: Macroeconomics, 2021, Forthcoming. 


\section{A Derivation of One-Period Bond Yield}

To derive the steady-state interest rate of the one-period bond of under the framework of Section 2.1, we consider the household problem:

$$
\begin{array}{rc}
\max _{c_{t}, B_{t}} & \mathbb{E}_{0} \sum_{t=0}^{\infty} \delta^{t} u\left(C_{t}\right), \\
\text { subject to: } & u\left(C_{t}\right)=\log \left[c_{t}+\nu\left(\Theta_{t}, \mathrm{GDP}_{t}, \xi_{t}\right)\right], \\
& P_{t} c_{t}+P_{t}^{T} B_{t} \leq B_{t-1}+\text { Transfers }_{t},
\end{array}
$$

where $c_{t}$ is consumption, $P_{t}$ is the nominal price level, $P_{t}^{T}$ is the price of purchasing one unit of one-period bond $B_{t}$, Transfers $t$ are the exogenous transfers to the household, GDP ${ }_{t}$ is the exogenous aggregate income of the economy, and $\Theta_{t}=\frac{P_{t}^{t} B_{t}}{P_{t}}$ denote the real holdings of safe assets.

We then assume that the utility from holding safe assets is homogeneous of degree one in the real income of the representative agent, $\mathrm{GDP}_{t}$, and real safe asset holdings, $\Theta_{t}$ :

$$
\nu\left(\Theta_{t}, \mathrm{GDP}_{t} ; \xi_{t}\right)=\mathrm{GDP}_{t} \cdot \nu\left(\theta_{t} ; \xi_{t}\right), \quad \text { where } \theta_{t}=\frac{\Theta_{t}}{\mathrm{GDP}_{t}}
$$

We also assume an increasing benefit of holding additional safe assets, $\nu^{\prime}>0$, but at a decreasing marginal rate, $\nu^{\prime \prime}<0$. Using Equation (A.4) in the maximization problem (A.1)-(A.3), and calculating the first-order conditions for consumption $c_{t}$ and one-period bond $B_{t}$, we get:

$$
u^{\prime}\left(C_{t}\right) \nu^{\prime}\left(\theta_{t} ; \xi_{t}\right) \frac{P_{t}^{T}}{P_{t}}-u^{\prime}\left(C_{t}\right) \frac{P_{t}^{T}}{P_{t}}+\mathbb{E}_{t} \delta \frac{u^{\prime}\left(C_{t+1}\right)}{P_{t+1}}=0
$$

After some algebra on Equation (A.5), we then get:

$$
P_{t}^{T}=\frac{1}{I_{t}}=\frac{1}{\left(1-\nu^{\prime}\left(\theta_{t} ; \xi_{t}\right)\right)} \mathbb{E}_{t}\left[\delta \frac{u^{\prime}\left(C_{t+1}\right)}{u^{\prime}\left(C_{t}\right)} \frac{1}{\Pi_{t+1}}\right]
$$

where $I_{t}$ is the nominal yield of the one-period bond, and $\Pi_{t}=P_{t} / P_{t-1}$ is the inflation 
rate. Using Equation (A.2) and doing some additional algebra, we then get:

$$
\begin{aligned}
\frac{1}{I_{t}} & =\frac{1}{\left(1-\nu^{\prime}\left(\theta_{t} ; \xi_{t}\right)\right)} \mathbb{E}_{t}\left[\delta \cdot \frac{1}{\Pi_{t+1}} \cdot \frac{c_{t}+\mathrm{GDP}_{t} \cdot \nu^{\prime}\left(\theta_{t} ; \xi_{t}\right)}{c_{t+1}+\mathrm{GDP}_{t+1} \cdot \nu^{\prime}\left(\theta_{t+1} ; \xi_{t+1}\right)}\right], \\
\frac{1}{I_{t}} & =\frac{1}{\left(1-\nu^{\prime}\left(\theta_{t} ; \xi_{t}\right)\right)} \mathbb{E}_{t}\left[\delta \cdot \frac{1}{\Pi_{t+1}} \cdot \frac{1+\frac{\mathrm{GDP}_{t}}{c_{t}} \cdot \nu^{\prime}\left(\theta_{t} ; \xi_{t}\right)}{\frac{c_{t+1}}{c_{t}}+\frac{\mathrm{GDP}_{t+1}}{c_{t}+1} \frac{c_{t+1}}{c_{t}} \cdot \nu^{\prime}\left(\theta_{t+1} ; \xi_{t+1}\right)}\right] .
\end{aligned}
$$

If we assume that the steady-state of this economy has a constant ratio of safe assets to GDP, $\theta$, and a constant consumption to GDP ratio, then the steady-state of the equation above is:

$$
I=\left[1-\nu^{\prime}(\theta ; \xi)\right] \Pi \frac{g}{\delta},
$$

where $g$ is the steady-state growth rate of consumption. 


\section{B Data Description}

\section{B.1 Data Sources}

The data set includes half-year data for Australia (AL), Canada (CA), Denmark (DN), euro area (EA), Japan (JA), Norway (NO), New Zealand (NZ), Sweden (SD), Switzerland (SZ), United Kingdom (UK), and United States (US). The sample period goes from 1960 to 2019 .

Unemployment rates: National agencies and Organisation for Economic Co-operation and Development (OECD)

Inflation rates: National agencies and Organisation for Economic Co-operation and Development (OECD)

Policy interest rates: National agencies and Organisation for Economic Co-operation and Development (OECD)

Long-term inflation expectations: Consensus 5-year-ahead consumer price inflation available in their April and October surveys. Different countries have different starting dates for these series. The data is not available for Denmark.

World international reserves holdings: financial assets of the central banks and monetary authorities that are held in different reserve currencies (e.g. the U.S. dollar, the Euro, and the Pound sterling) and which are used to back its liabilities (e.g. the local currency issued and the various bank reserves deposited with the central bank by the government or financial institutions). obtained from the IMF.

Currency composition of world international reserves: obtained from the IMF Currency Composition of Official Foreign Exchange Reserves (COFER) database, which shows the evolution of the currency composition of international reserves. Since 2017, eight currencies are distinguished in COFER data: U.S. dollar; euro; Chinese renminbi; Japanese yen; pound sterling; Australian dollar; Canadian dollar; and Swiss franc. All other currencies are included and indistinguishable in the category other currencies.

U.S. gross government debt, marketable debt and non-marketable debt: obtained from U.S. Treasury Monthly Statement of Public Debt (MPSD). 
Foreign governments holdings of safe assets in the United States: obtained from the IMF Currency Composition of Official Foreign Exchange Reserves (COFER) database from 1960-1984; and obtained from U.S. Treasury International Capital (TIC) System adjusted using the methodology in Bertaut and Judson (2014) to exclude foreign government holdings of unsafe assets in the U.S. from 1984-2019 .

Germany's gross government debt, marketable debt and non-marketable debt: obtained from Deutsche Bundesbank Monthly Bulletin (Table IX).

France's gross government debt, marketable debt and non-marketable debt: obtained from IMF's Historical Public Debt Database (HPDD) from 1960-1997; and obtained from National Institute of Statistics and Economic Studies (INSEE) from 1998-2019.

U.K. gross government debt, marketable debt and non-marketable debt: obtained from Ellison and Scott (2020) from 1960-1966; and obtained from the Office of National Statistics Public Sector Finance Statistics (ONS) from 1967-2019.

Foreign governments holdings of safe assets in Germany, France, and the U.K.: we calculate international reserves holdings in euros and pound sterling using the IMF Currency Composition of Official Foreign Exchange Reserves (COFER) database. We also use data from Jones (2018) to exclude deposits of Central Banks with foreign commercial banks (excluding the United States), foreign central banks, BIS and the IMF from the measure of international reserves holdings, obtaining a measure of international reserves allocated in safe government bonds.

Productivity growth: Trend-productivity growth is the trend of an average of four different yearly measures of productivity: total factor productivity, GDP per person employed, and two measures of GDP per hour worked obtained from the Long-Term Productivity Database ${ }^{32}$ (LTP) and the Conference Board Total Economy Database (TED). To obtain the trend, we use an HP-filter smoothing parameter of 2500 on the (interpolated) quarterly data before turning it into half-yearly data.

Birth rate: average annual number of births during a year per 1,000 persons in the population at midyear. Obtained from the United Nations' 2019 Revision of World Population Prospects (WPP2019).

\footnotetext{
${ }^{32}$ For details, see Bergeaud et al. (2016).
} 
Working-age population share: is the ratio of working-age population (people aged 20 to 60 ) to total population. Obtained from the United Nations' 2019 Revision of World Population Prospects (WPP2019).

Convenience yield: As in Gilchrist and Zakrajšek (2012), we start with bond yields quoted in secondary markets from the Lehman/Warga and Merrill/Lynch ${ }^{33}$ databases for the period 1973-2018. We then obtain spreads by subtracting the yield from U.S. Treasuries with the exact same maturity using the yield curve estimated by Gürkaynak et al. (2007). Then, we use the cross-sectional median of these spreads at each period, calling it convenience yield. For years before 1973, we use the spread between the Moody's AAA yields and 20-year U.S. Treasuries. We then extract the trend of the convenience yield to bypass cyclical fluctuations and focus only on long-run developments. To obtain the trend, we use an HP-filter with smoothing parameter of 10000 on the quarterly data before turning it into half-yearly data. We choose this very large smoothing parameter because of the strong cyclicality of the convenience yield.

\footnotetext{
${ }^{33}$ ICE Data Indices, LLC, used with permission.
} 


\section{State-Space Model Details}

\section{C.1 Data on the State-Space Model}

To avoid estimating a negative unemployment rate, we estimate our state-space model on a transformed series of unemployment rates. Readings $x$ greater than $1 \%$ are left unchanged, while readings $x$ less than $1 \%$ become $(1+\log (x))$ percent. Implicitly, this transformation assumes an increasing elasticity of other variables to (untransformed) unemployment rates less than 1\%. For instance, this assumption is consistent with a convex Phillips curve for unemployment rates less 1\%. Hooper et al. (2019) find evidence of such convex relationship for the United States in the 1950s and 1960s, consistent with the few observations of less than $1 \%$ unemployment rates and high inflation rates in our sample during the 1970s.

\section{C.2 Prior and Posterior Distributions}

We first give brief description of the priors not discussed in Section 3.3. Priors for the elements of $B$ are centered around the assumption that $\hat{Y}_{j, t}$ 's follow univariate $\mathrm{AR}(1)$ processes, inspired by Minnesota-style priors. Priors for the elements of $C$ with sign restrictions $\left(C_{1,2}\right.$, $C_{2,2}, C_{2,4}$, and $C_{1,6}$ ) follow gamma distributions, while the priors for all remaining elements of $C$ follow normal distributions. Priors for the standard deviations $\left(\phi^{m}, \phi^{p}, \phi^{u}, \phi^{d}, \phi^{s}, \phi^{r}\right)$ of the shocks $\left(x_{j, t}^{m}, z_{j, t}^{p}, x_{j, t}^{u}, z_{j, t}^{d}, z_{j, t}^{s}, \epsilon_{j, t}\right)$ follow gamma distributions. The prior distribution for the persistence of the demand shocks $\left(\rho^{d}\right)$ follows a beta distribution.

Prior and posterior distributions of all model parameters are described in Table 4 . We also report the probability density functions of the priors and posteriors of the parameters related to the drivers of neutral interest rates in Figure C.1.

\section{C.3 Real Neutral Rates, Inflation and Unemployment Trends}

Figure C.2 displays the real neutral interest rate of the United States, Canada, United Kingdom, and the euro area, as well as their realized real interest rates. Figure C.3 details the evolution of inflation in the same of economies. Inflation trends are the long-term inflation expectations for these economies starting in the 1990s, while before this period these trends are estimated by the model. Figure C.4 reports unemployment rates and our estimates for unemployment rate trends across the same economies. 
TABLE 4

Parameters: Prior and Posterior Distributions

\begin{tabular}{|c|c|c|c|c|c|c|c|}
\hline \multirow[b]{2}{*}{ Parameter } & \multicolumn{4}{|c|}{ Prior Distribution } & \multicolumn{3}{|c|}{ Posterior Distribution } \\
\hline & Distribution & Median & 10th & 90 th & Median & 10th & 90th \\
\hline$B_{1,1}$ & Beta & 0.73 & 0.41 & 0.94 & 0.88 & 0.85 & 0.90 \\
\hline$B_{1,2}$ & Normal & 0.00 & -0.32 & 0.32 & 0.00 & -0.01 & 0.01 \\
\hline$B_{1,3}$ & Normal & 0.00 & -0.32 & 0.32 & 0.08 & 0.07 & 0.10 \\
\hline$B_{2,1}$ & Normal & 0.00 & -0.32 & 0.32 & -0.23 & -0.30 & -0.16 \\
\hline$B_{2,2}$ & Beta & 0.73 & 0.41 & 0.94 & 0.53 & 0.48 & 0.58 \\
\hline$B_{2,3}$ & Normal & 0.00 & -0.32 & 0.32 & 0.21 & 0.17 & 0.25 \\
\hline$B_{3,1}$ & Normal & 0.00 & -0.32 & 0.32 & 0.17 & 0.12 & 0.23 \\
\hline$B_{3,2}$ & Normal & 0.00 & -0.32 & 0.32 & 0.09 & 0.06 & 0.11 \\
\hline$B_{3,3}$ & Beta & 0.73 & 0.41 & 0.94 & 0.85 & 0.82 & 0.88 \\
\hline$C_{1,1}$ & Normal & 0.00 & -0.64 & 0.64 & -0.10 & -0.19 & -0.01 \\
\hline$C_{1,2}$ & Gamma & 0.35 & 0.05 & 1.15 & 0.11 & 0.03 & 0.41 \\
\hline$C_{1,3}$ & Normal & -1.00 & -1.64 & -0.36 & -0.77 & -0.88 & -0.66 \\
\hline$C_{1,6}$ & Gamma & 0.35 & 0.05 & 1.15 & 0.03 & 0.01 & 0.05 \\
\hline$C_{2,1}$ & Normal & -1.00 & -1.64 & -0.36 & -1.22 & -1.75 & -0.70 \\
\hline$C_{2,2}$ & Gamma & 0.69 & 0.11 & 2.30 & 0.91 & 0.14 & 2.74 \\
\hline$C_{2,3}$ & Normal & 0.00 & -1.28 & 1.28 & -1.25 & -2.51 & 0.11 \\
\hline$C_{2,4}$ & Gamma & 0.35 & 0.05 & 1.15 & 1.12 & 0.79 & 1.46 \\
\hline$C_{3,1}$ & Normal & -1.00 & -1.64 & -0.36 & -0.36 & -0.79 & 0.06 \\
\hline$C_{3,3}$ & Normal & 0.00 & -1.28 & 1.28 & 1.68 & 0.79 & 2.45 \\
\hline$C_{3,4}$ & Normal & 0.00 & -1.28 & 1.28 & 1.59 & 1.43 & 1.76 \\
\hline$C_{3,6}$ & Normal & 0.00 & -1.28 & 1.28 & 0.32 & 0.18 & 0.52 \\
\hline$\phi^{m}$ & Gamma & 0.18 & 0.09 & 0.33 & 0.20 & 0.20 & 0.21 \\
\hline$\phi^{p}$ & Gamma & 0.69 & 0.11 & 2.30 & 0.35 & 0.04 & 0.72 \\
\hline$\phi^{u}$ & Gamma & 0.18 & 0.09 & 0.33 & 0.37 & 0.26 & 0.48 \\
\hline$\phi^{d}$ & Gamma & 0.69 & 0.11 & 2.30 & 0.35 & 0.34 & 0.37 \\
\hline$\phi^{r}$ & Gamma & 0.18 & 0.09 & 0.33 & 0.17 & 0.09 & 0.29 \\
\hline$\phi^{s}$ & Gamma & 0.69 & 0.11 & 2.30 & 1.82 & 1.51 & 1.97 \\
\hline$\rho^{d}$ & Beta & 0.50 & 0.23 & 0.77 & 0.62 & 0.57 & 0.67 \\
\hline$\beta_{p t}$ & Normal & 0.00 & -0.64 & 0.64 & 0.59 & 0.36 & 0.85 \\
\hline$\beta_{w s}$ & Normal & 0.00 & -0.32 & 0.32 & 0.14 & -0.01 & 0.27 \\
\hline$\beta_{s a}$ & Normal & 0.00 & -0.10 & 0.10 & 0.16 & 0.09 & 0.24 \\
\hline$\beta_{c y}$ & Normal & 0.00 & -1.28 & 1.28 & -2.17 & -3.25 & -1.10 \\
\hline$\beta_{\text {row }}$ & Beta & 0.50 & 0.16 & 0.84 & 0.75 & 0.44 & 0.93 \\
\hline
\end{tabular}

NotE: The table shows statistics about prior and posterior distributions of all estimated parameters of the model. 
Figure C.1

Density of Parameters Determining Neutral Real Rates

(A) Safe Assets $\left(\beta_{s a}\right)$

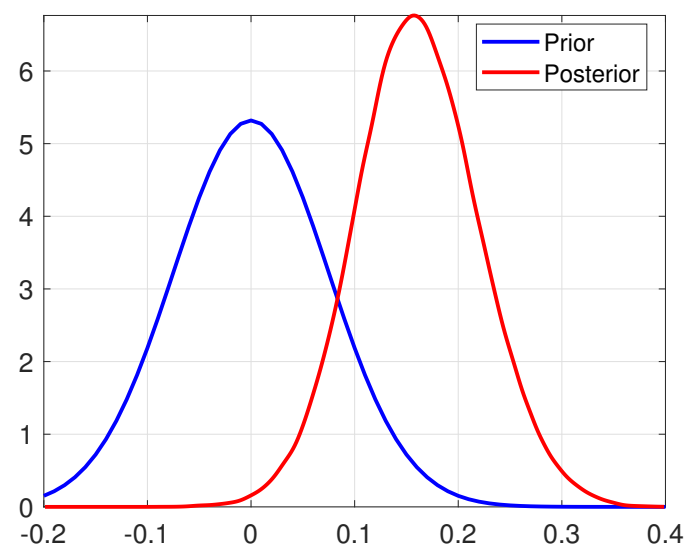

(B) Productivity $\left(\beta_{p t}\right)$

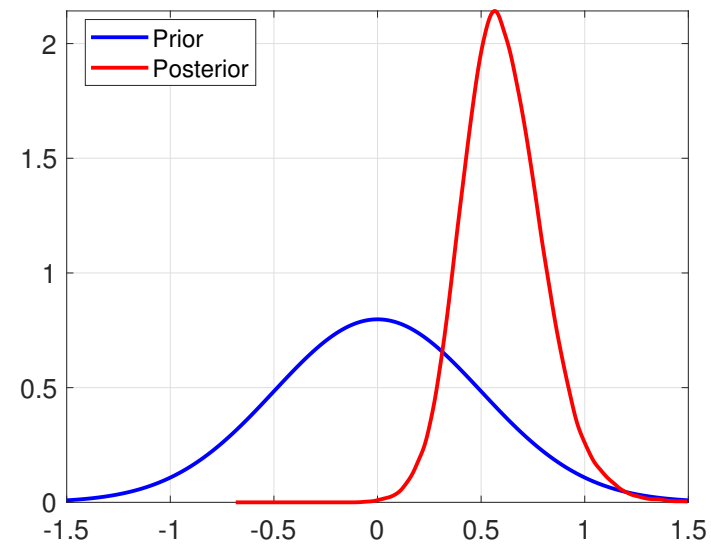

(D) Convenience Yield $\left(\beta_{c y}\right)$

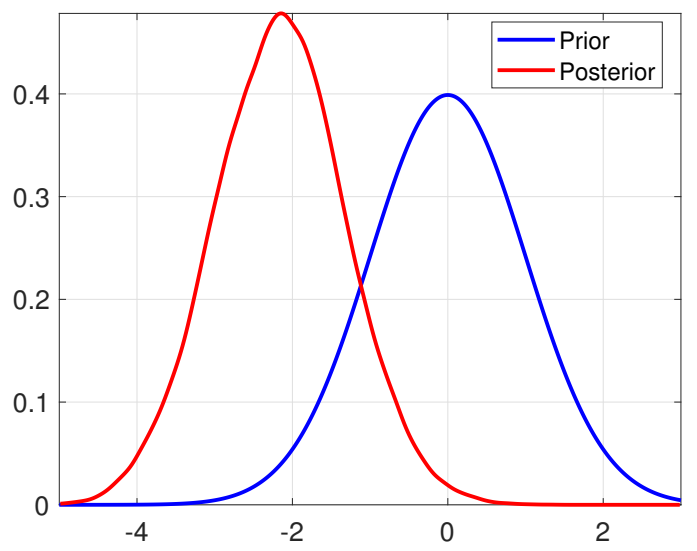

(C) Working-Age Share $\left(\beta_{w s}\right)$

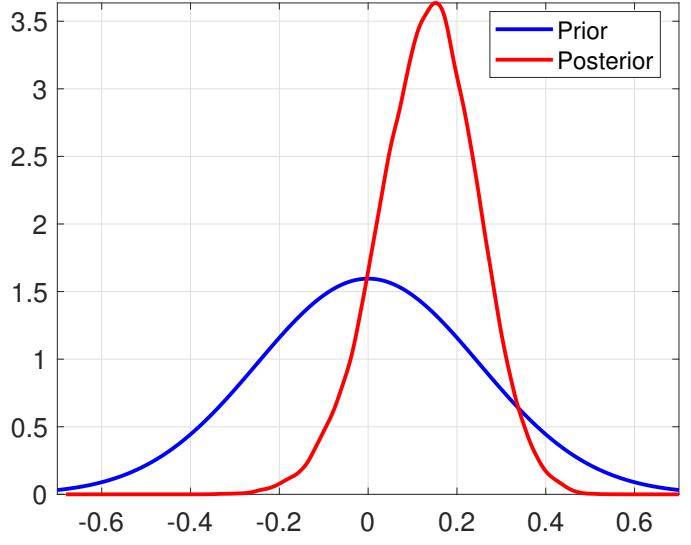

(E) Global Spillovers $\left(\beta_{\text {row }}\right)$

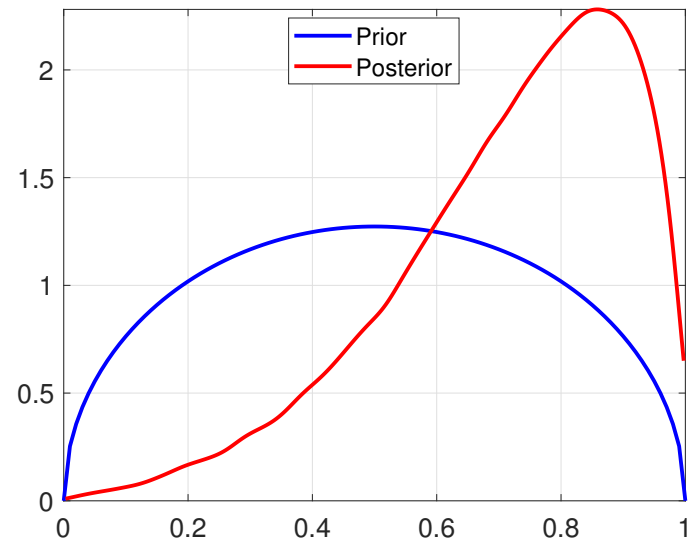

Note: The figure shows the prior (blue line) and posterior (red line) distributions of the elasticity of neutral rates to the following determinants: net supply of safe assets $\left(\beta_{s a}\right)$, trend-productivity $\left(\beta_{p t}\right)$, working age share of the population $\left(\beta_{w s}\right)$, global spillovers from country specific factors $\left(\beta_{\text {row }}\right)$, and convenience yield $\left(\beta_{c y}\right)$. See Section 3 for details about the model and its variables. 
Figure C.2

Real Interest Rates across Select Advanced Economies

(A) United States

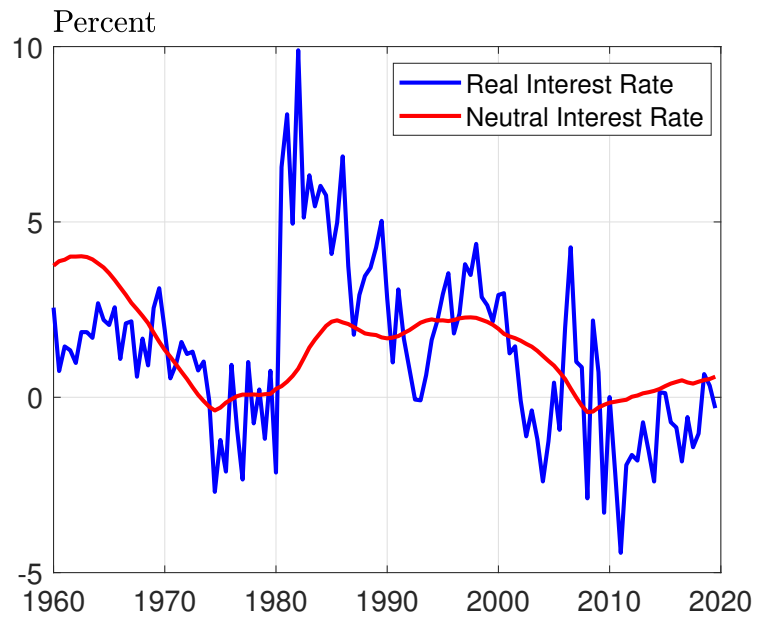

(C) Euro Area

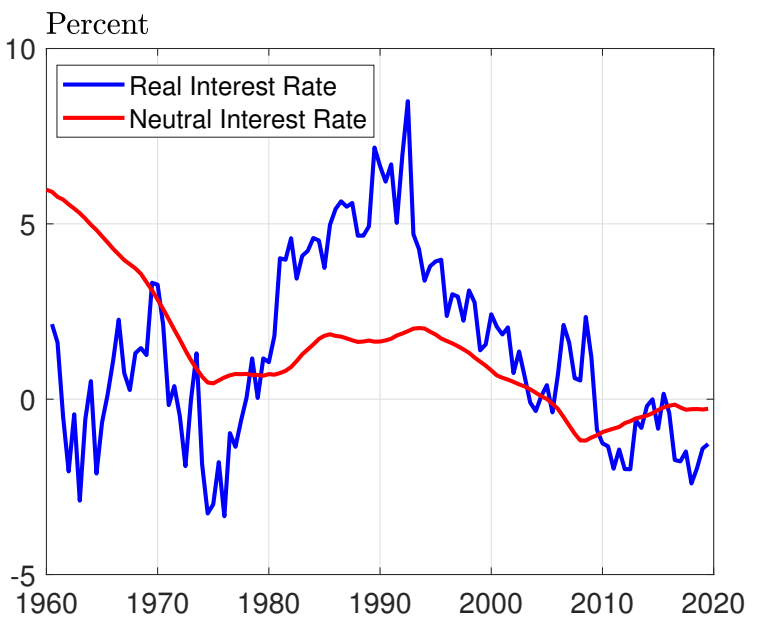

(B) Canada

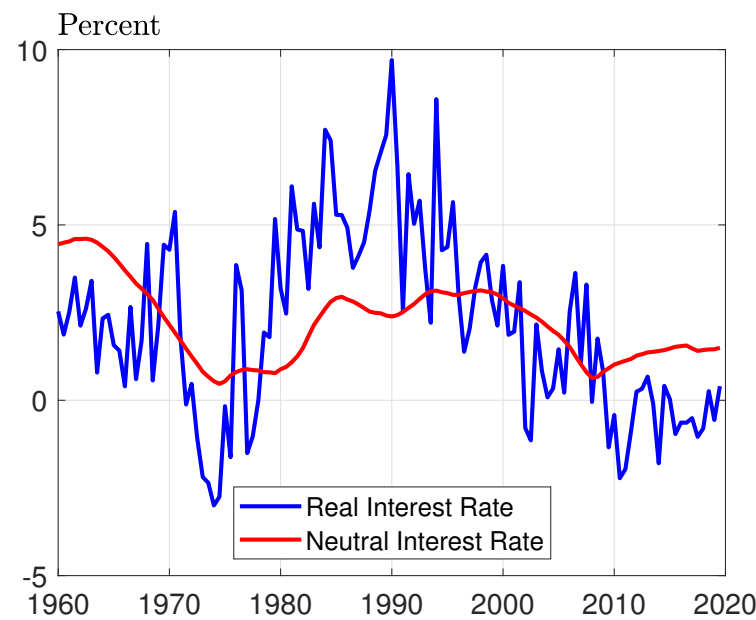

(D) United Kingdom

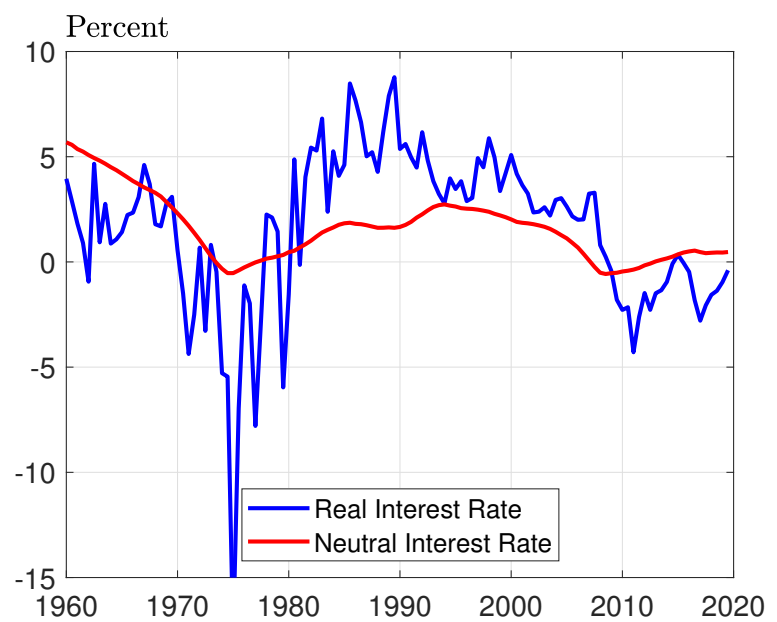

Note: Real interest rates (blue lines) are measured as the difference between the policy interest rate and the realized inflation. Neutral interest rates (red lines) are estimated by the model of Section 3 using the median values of the posterior distribution of parameters. 
Figure C.3

Inflation Rates Across Select Advanced Economies

(A) United States

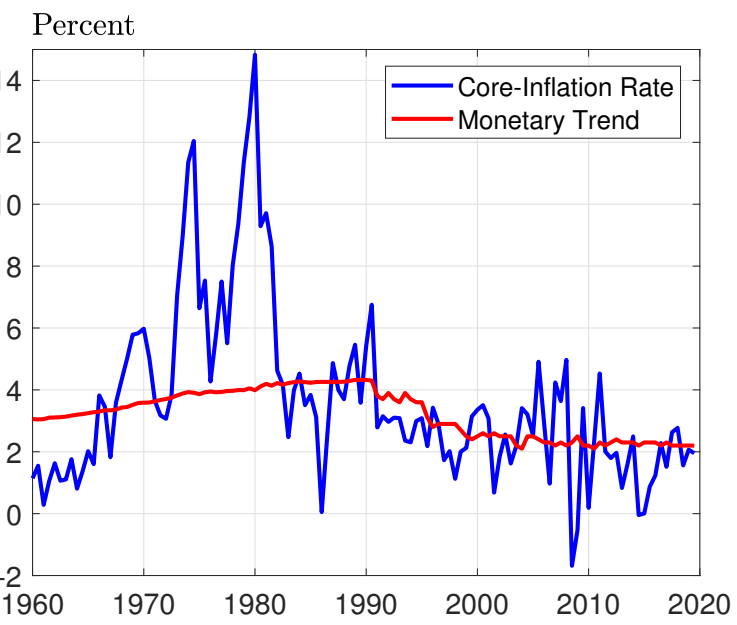

(c) Euro Area

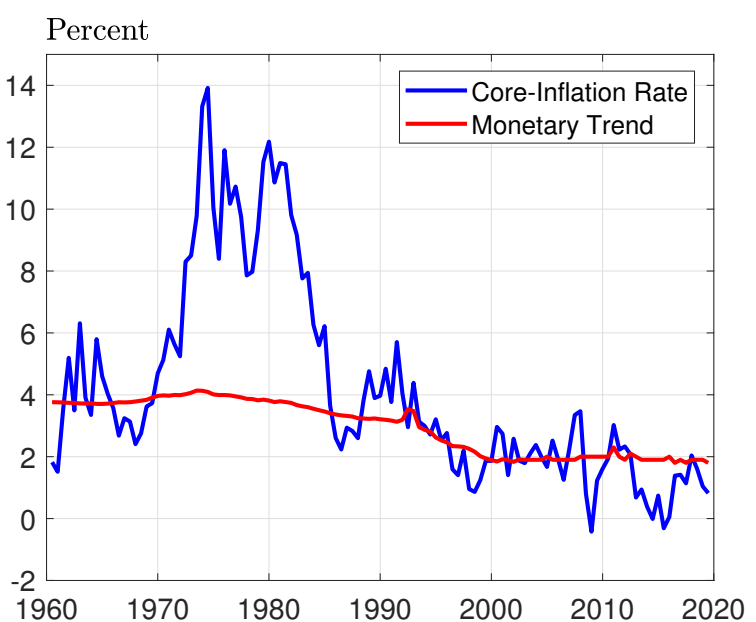

(в) Canada

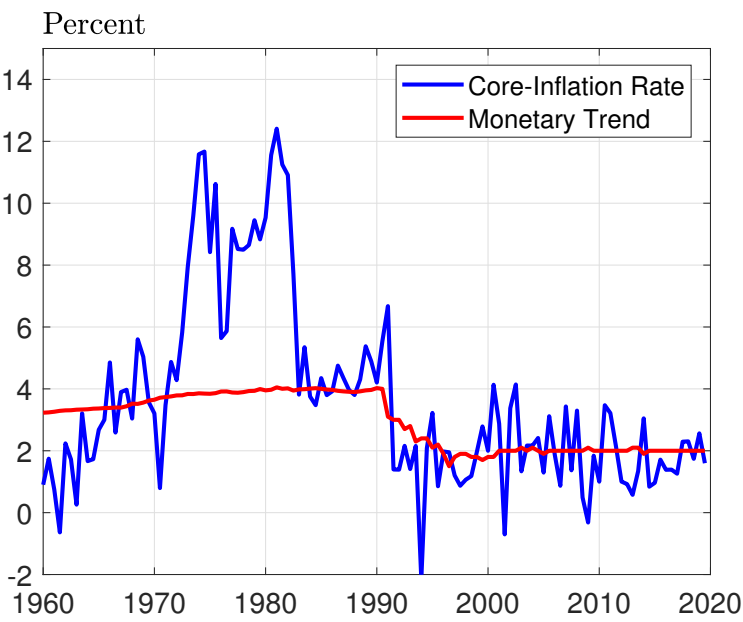

(D) United Kingdom

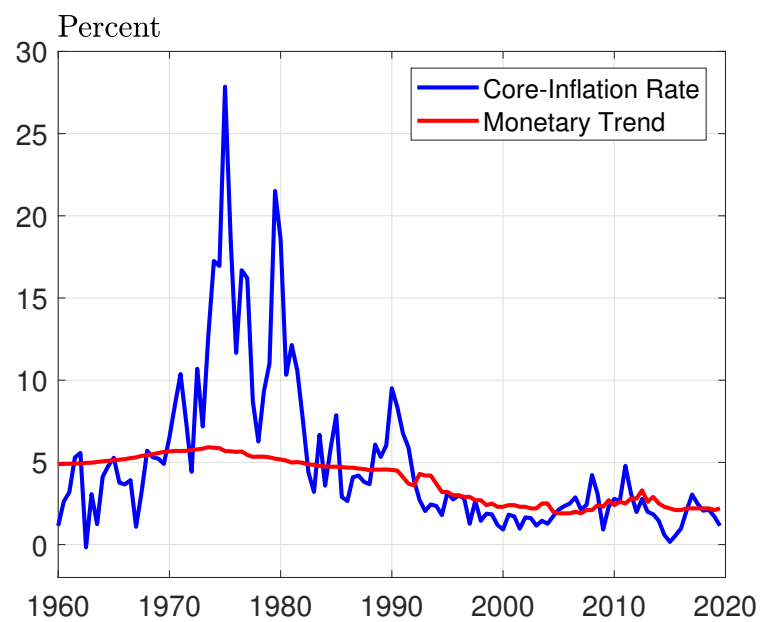

Note: Inflation rates (blue lines) are taken from databases in national agencies and the Organisation for Economic Co-operation and Development. Monetary trends (red lines) are either the 5-year ahead inflation expectations from Consensus when available or the estimated series when the data is missing. In the latter case, we use the median values of the estimated permanent monetary shocks. 
Figure C.4

\section{Unemployment Rates across Select Advanced Economies}

(A) United States

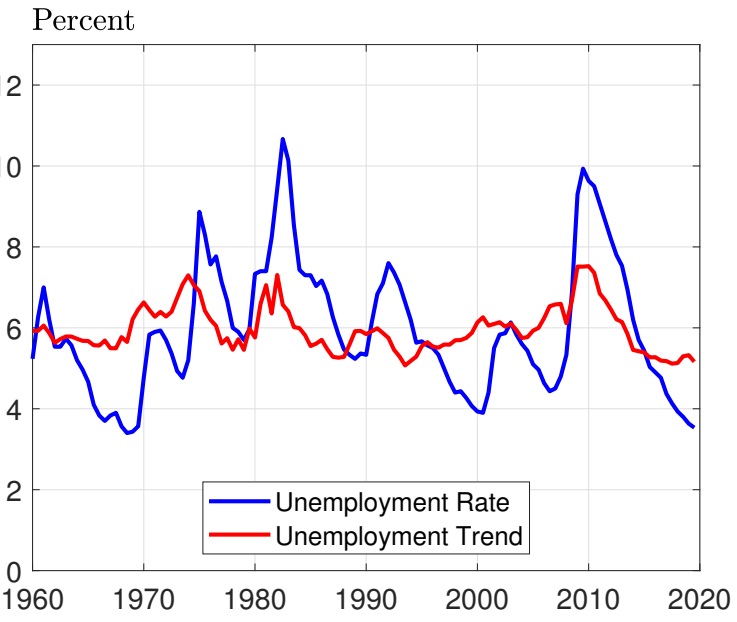

(C) Euro Area

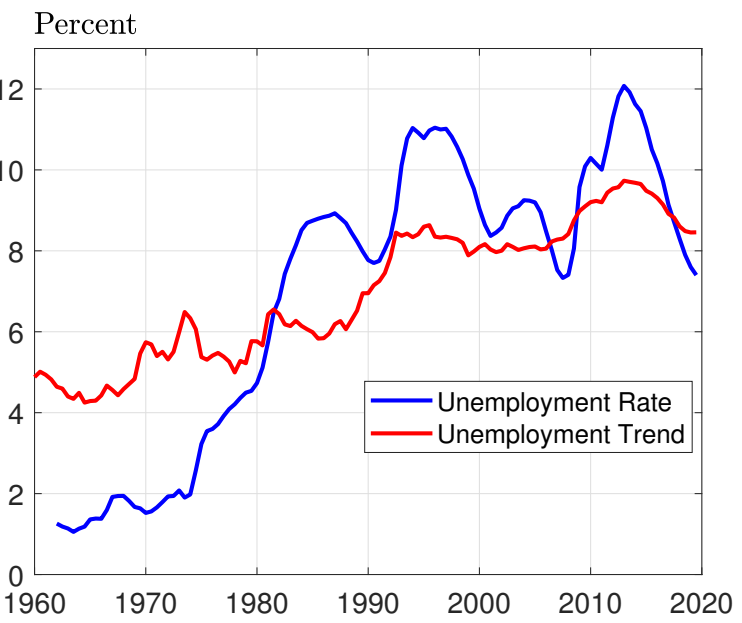

(B) Canada

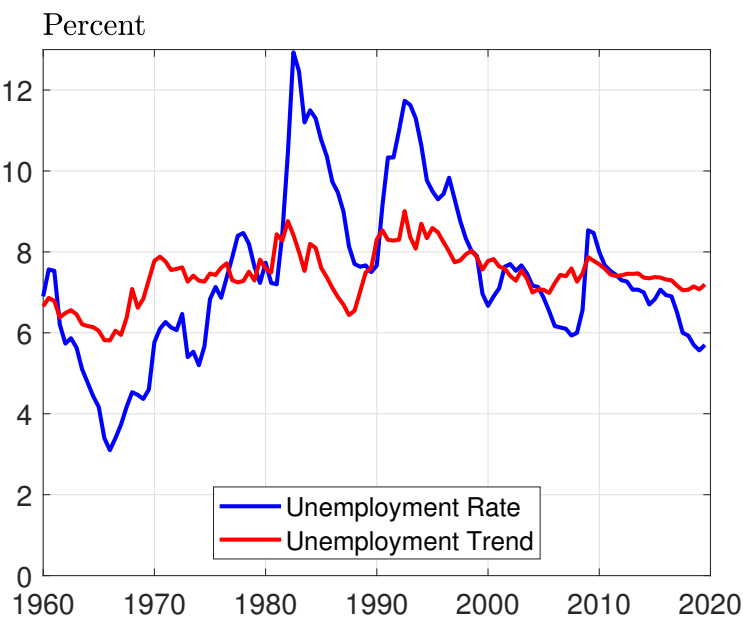

(D) United Kingdom

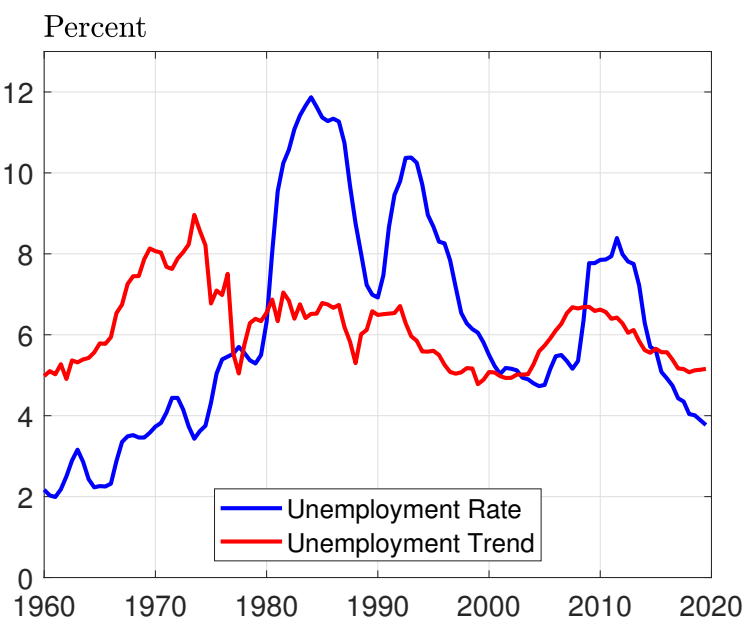

Note: Unemployment rates (blue lines) are taken from databases in national agencies and the Organisation for Economic Co-operation and Development. Unemployment trends (red lines) are estimated by the model of Section 3 using the median values of the permanent unemployment rate shocks. 


\section{Details about Alternative Specifications}

In this section, we provide details on the alternative specifications discussed in Section 4.7.

Two lags in Vector Autoregression of cyclical variables. We increase the number of lags in Equation (5) from 1 to 2, thus increasing the number of parameters estimated.

Birth rate as the demographic variable. We substitute the working-age share by birth rate (Figure D.1a) as the demographic variable in Equation (6). While we could have used population shares of other age groups as the demographic variable in our estimation, these other shares are highly colinear with our working-age share measure.

Net supply of safe assets of advanced economies. We use the net supply of safe assets of United States, Germany, France and the United Kingdom (Figure 2b) in the estimation of the model instead of the baseline net supply of safe assets (Figure 3d).

Endogenous net supply of safe assets. In principle, it is possible that our measure of net supply of safe assets reacts to demand shocks for U.S. Treasuries, or more generally to lower levels of interest rates. In this case, the fiscal authority would take advantage of market conditions to issue more debt, thus implying a negative correlation between the supply of Treasuries and safe interest rates. These circumstances would imply an attenuation bias in our approach, given the positive correlation observed in the data. However, as argued by Krishnamurthy and Vissing-Jorgensen (2012), we view large and lasting movements in the supply of Treasuries as likely insensitive to demand shocks and business cycle conditions. To support our view, we decompose the net supply of safe assets into cyclical and trend components. The cyclical component may be affected by U.S. unemployment, inflation, and policy rates. The trend component evolves as a random walk. We then assume that changes in neutral interest rates depend on changes in the trend of net supply of safe assets. In this alternative specification, not only is the posterior distribution of $\beta_{s a}$ very similar to the one of the baseline model (Figure 8), but also the marginal likelihood is 3.3 log-points lower than the baseline model.

Net supply of safe assets excluding Treasury holdings by the Federal Reserve. This measure is shown in Figure D.1b (purple line), and we use it in the estimation of the model instead of the baseline net supply of safe assets (Figure 3d) . There is an important 
debate about whether an increase in these Fed holdings decreases the amount of safe assets available to the private sector. On one hand, an increase in central bank holdings of sovereign debt only shifts the holdings of the private sector from sovereign debt to cash (reserve balances in the central bank), thus not changing the nominal amount of net safe assets available to private agents. On the other hand, this shift from sovereign debt to cash in the hands of the private sector might decrease the amount of "effective safe assets" (Caballero and Farhi (2018)). The reason is that returns on sovereign debt are negatively correlated with economic activity, thus implying an insurance value for such asset and increasing its "effective safety." Returns of reserve balances are invariant to the economic cycle, thus decreasing their "effective safety."

Alternative trends for productivity growth and convenience yield. In Section 4.7, we report the results from a specification that uses the univariate two-year-ahead forecast for productivity growth and convenience yield as their trends, as advocated by Hamilton (2018). We have also estimated the model using a 5-year moving average of these variables, reaching similar results. Finally, we have also used the HP-filtered trend of the residuals of the convenience yield from a regression on net safe assets, yielding similar results to our baseline model. This last robustness exercise is motivated by the argument that the convenience yield may already reflect the pricing of the scarcity of safe assets that is originated in the supply of these assets.

Adding 10-year interest rates to the model. We incorporate in our model nominal 10-year rates for our sampled 11 countries, in addition to unemployment, inflation and policy rates. To do so, we replace Equations (3) and (5) by:

$$
\begin{gathered}
Y_{j, t} \equiv \underbrace{\left[\begin{array}{c}
u_{j, t} \\
\pi_{j, t} \\
i_{j, t} \\
l_{j, t}
\end{array}\right]}_{\text {Data }} \equiv \underbrace{\left[\begin{array}{c}
\widehat{u}_{j, t} \\
\widehat{\pi}_{j, t} \\
\widehat{i}_{j, t} \\
\widehat{l}_{j, t}
\end{array}\right]}_{\text {Cyclical }}+\left[\begin{array}{ccc}
1 & 0 & 0 \\
0 & 1 & 0 \\
0 & 1 & 1 \\
0 & 1 & 1
\end{array}\right] \cdot \underbrace{\left[\begin{array}{c}
X_{j, t}^{u} \\
X_{j, t}^{m} \\
X_{j, t}^{r}
\end{array}\right]}_{\text {Trend }} \\
\widehat{Y}_{j, t}=B \cdot \widehat{Y}_{j, t-1}+C \cdot Z_{j, t}, \quad \widehat{Y}_{j, t}=\left[\begin{array}{lll}
\widehat{u}_{j, t} & \widehat{\pi}_{j, t} \widehat{i}_{j, t} & \widehat{l}_{j, t}
\end{array}\right]^{\prime},
\end{gathered}
$$

where we have unemployment, $u_{j, t}$, inflation, $\pi_{j, t}$, policy, $i_{j, t}, 10$-year, $l_{j, t}$, rates for country 
$j$ and time $t$. In effect, monetary trends are common to inflation, policy and 10-year rates, while the real neutral interest rate is common to the latter two. We also add the change in long-run real interest rates (Figure D.1c) as an observable variable in the model, analogously to Equation (9). Then, we change the rest of the model accordingly.

Turning-off global spillovers. We impose that $\beta_{\text {row }}=0$ in the estimation of our model. Excluding long-term inflation expectations from the estimation. We exclude the observation equation (11) from our estimation. 


\section{Data used in Selected Alternative Model Specifications}

(A) Birth Rates

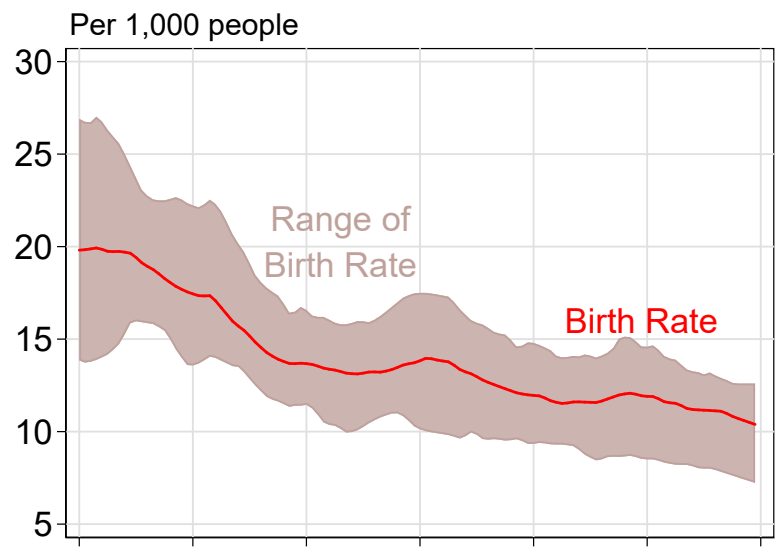

1960h1 1970h1 1980h1 1990h1 2000h1 2010h1 2020h1
(B) Net Supply of Safe Assets

Percentage of World GDP

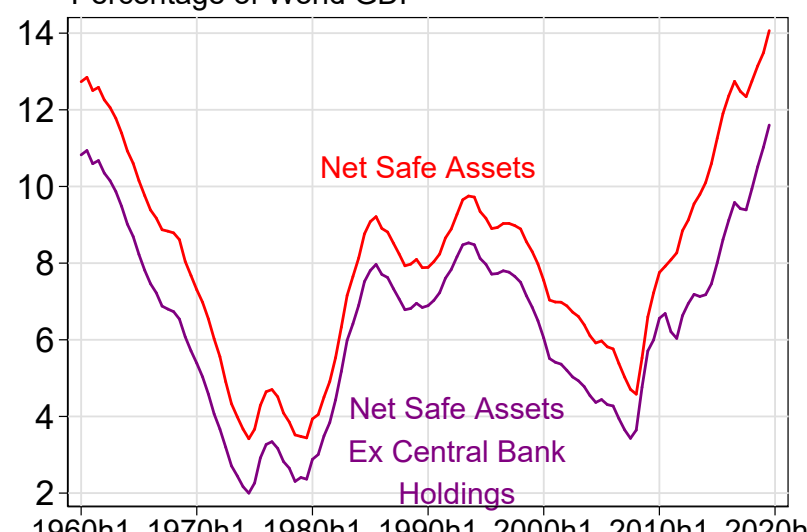

(C) Long Real Interest Rates

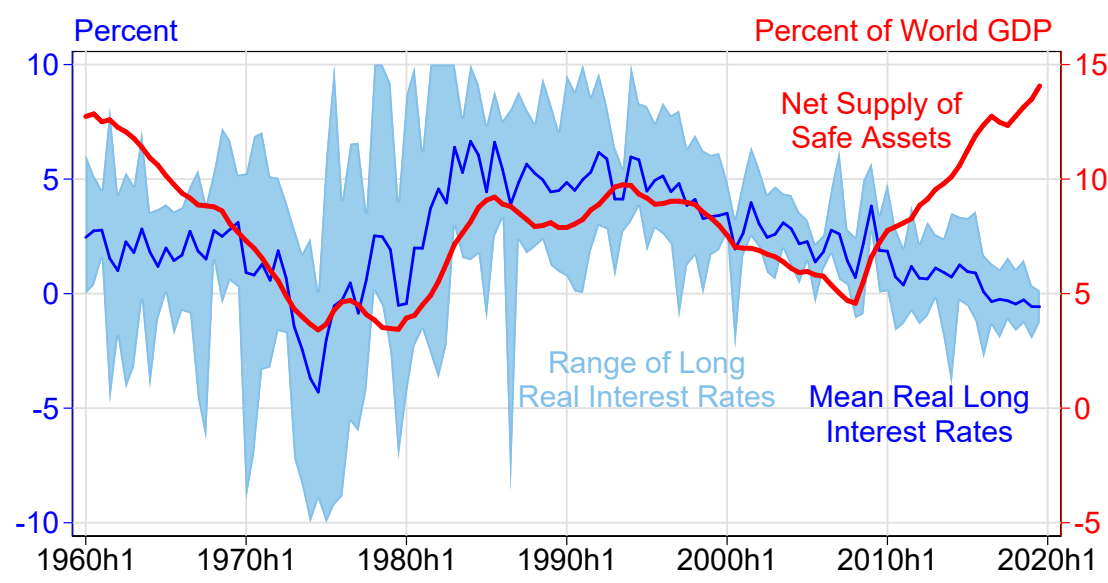

Note: Figure D.1a displays the birth rate measured as the average annual number of births during a year per 1,000 persons. Figure D.1b shows the baseline series of net supply of safe assets (red line) and an alternative series that differs from the previous one by also excluding Federal Reserve holdings of U.S. Treasury securities (purple line). In Figure D.1c, the shaded blue area displays the range of long real interest rates, measured by 10-year rates minus realized inflation, while the solid blue line is the mean real interest rate. For a better exposition, Figure D.1c excludes values of real rates greater than $10 \%$ and less than negative 10\%. The red line is our measure of net supply of U.S. Treasuries (Section 2.2). 